On the links between stock and commodity markets' volatility 


\section{TABLE OF CONTENTS}

Non-technical summary. . . . . . . . . . . . . . . . . . . . . . . . . . . 3

Abstract . . . . . . . . . . . . . . . . . . . . . . . . . . . . . 4

Résumé non technique . . . . . . . . . . . . . . . . . . . . . 5

Résumé court . . . . . . . . . . . . . . . . . . . . . . . . . . . . . 6

1. Introduction . . . . . . . . . . . . . . . . . . . . . . . . . . . . . . 7

2. Literature review . . . . . . . . . . . . . . . . . . . . . . 12

3. Data and stylized facts . . . . . . . . . . . . . . . . . . . . . . . . . 13

4. Methodology . . . . . . . . . . . . . . . . . . . . . . . . 14

5. Results . . . . . . . . . . . . . . . . . . . . . . . . . 16

6. Conclusion . . . . . . . . . . . . . . . . . . . . . . . . . . . . . . 18

List of working papers released by CEPII. . . . . . . . . . . . . . . . . . . . प 


\title{
ON THE LINKS BETWEEN STOCK AND COMMODITY MARKETS' VOLATILITY
}

\author{
Anna Creti, Marc Joëts, Valérie Mignon
}

\section{NON-TECHNICAL SUMMARY}

This paper contributes to the emerging empirical literature dealing with the relationships between commodity and stock markets. More specifically, we focus on the dynamics of the correlations between both markets, and analyze whether those correlations evolve according to the situation-bullish or bearish-in the stock market.

We pay a particular attention to the recent 2007-2008 financial crisis by investigating whether it has strengthened or disrupted the links between stock and commodity markets. From a methodological viewpoint, we follow the dynamic conditional correlation (DCC) GARCH approach which allows to assess the changes in correlations between commodity and stock returns over time.

Our sample consists of 25 commodities covering various sectors over the period from January 3, 2001 to November 28, 2011. Relying on a large panel of raw materials (energy, metals, agricultural, food, ...) allows us to study whether commodities constitute an homogenous asset class with regard to their links with stock markets, and whether the crisis has engendered a financialization of commodity markets.

Our results show that correlations between commodity and stock markets are time-varying and highly volatile. The impact of the 2007-2008 financial crisis is noticeable, emphasizing the links between commodity and stock markets, and highlighting the financialization of commodity markets. We also show that, while sharing some common features, commodities cannot be considered a homogeneous asset class: a speculation phenomenon is for instance highlighted for oil, coffee and cocoa, while the safe-haven role of gold is evidenced. 


\begin{abstract}
This paper investigates the links between price returns for 25 commodities and stocks over the period from January 2001 to November 2011, by paying a particular attention to energy raw materials. Relying on the dynamic conditional correlation (DCC) GARCH methodology, we show that the correlations between commodity and stock markets evolve through time and are highly volatile, particularly since the 2007-2008 financial crisis. The latter has played a key role, emphasizing the links between commodity and stock markets, and underlining the financialization of commodity markets. At the idiosyncratic level, a speculation phenomenon is highlighted for oil, coffee and cocoa, while the safe-haven role of gold is evidenced.
\end{abstract}

JEL Classification: C22, G01, G10, Q4.

Key Words: $\quad$ Commodities, stock market, financial crisis, volatility, correlations, DCC-GARCH. 


\section{LES LIENS ENTRE LA VOLATILITE DES MARCHES BOURSIERS ET DES MATIERES PREMIERES}

Anna Creti, Marc Joëts, Valérie Mignon

\section{RESUME NON TECHNIQUE}

Cet article contribue à la littérature empirique récente portant sur les relations entre les marchés des matières premières et les marchés boursiers. Plus précisément, nous étudions la dynamique des corrélations entre les deux types de marchés et analysons si celles-ci évoluent en fonction de la situation — haussière ou baissière — du marché boursier.

Nous accordons une attention particulière à la récente crise financière de 2007-2008 en examinant si celle-ci a renforcé ou perturbé les liens entre les marchés boursiers et les marchés des matières premières. D'un point de vue méthodologique, nous recourons aux modèles de volatilité avec corrélations conditionnelles dynamiques (approche DCC-GARCH) afin d'appréhender l'évolution des corrélations entre les deux types de marchés au cours du temps.

Notre échantillon est constitué de 25 matières premières couvrant différents secteurs sur la période allant du 3 janvier 2001 au 28 novembre 2011. Considérer un large panel de matières premières (énergie, métaux, produits agricoles, alimentaires, ...) nous permet d'étudier, d'une part, si celles-ci constituent une classe d'actifs homogène au regard de leurs liens avec les marchés boursiers, et, d'autre part, si la crise a engendré une financiarisation des marchés de matières premières.

Nos résultats montrent que les corrélations entre les marchés des matières premières et des actions évoluent au cours du temps et sont fortement volatiles, en particulier depuis la crise financière de 2007-2008. Cette dernière a joué un rôle clé, en renforçant les liens entre les deux types de marchés, mettant ainsi en évidence une financiarisation accrue des marchés de commodités. Au niveau individuel, le pétrole, le café et le cacao sont soumis à la spéculation, tandis que l'or joue le rôle de valeur refuge. 


\section{RESUME COURT}

Cet article étudie les liens entre les variations des prix de 25 matières premières et des cours des actions sur la période allant de janvier 2001 à novembre 2011, en accordant une attention particulière aux matières premières énergétiques. En recourant aux modèles de volatilité avec corrélations conditionnelles dynamiques (approche DCC-GARCH), nous montrons que les corrélations entre les marchés des matières premières et des actions évoluent au cours du temps et sont fortement volatiles, en particulier depuis la crise financière de 2007-2008. Cette dernière a joué un rôle clé, en renforçant les liens entre les deux types de marchés, mettant ainsi en évidence une financiarisation accrue des marchés de commodités. Au niveau individuel, le pétrole, le café et le cacao sont soumis à la spéculation, tandis que l'or joue le rôle de valeur refuge.

Classification JEL : C22, G01, G10, Q4.

Mots-clefs : $\quad$ Matières premières, marché boursier, crise financière, volatilité, corrélations, DCC-GARCH. 


\title{
ON THE LINKS BETWEEN STOCK AND COMMODITY MARKETS' VOLATILITY ${ }^{1}$
}

\author{
Anna Creti*, Marc Joëts ${ }^{\dagger}$, and Valérie Mignon ${ }^{\ddagger}$
}

\section{INTRODUCTION}

Throughout the last decade, commodity prices experienced an exceptional volatility, with simultaneous and alternating phases of rising and falling trends. This evolution can be compared to that of financial markets, as illustrated by Figures 1 and 2 representing the Standard and Poor's 500 (S\&P 500) and Commodity Research Bureau (CRB) price returns' volatility. As shown in Figure 3-which displays the dynamics of the S\&P 500 and CRB price indexescommodity prices have experienced a drop during the 2007-2008 financial crisis, and their link to stock prices seems to have strengthened since that turmoil. At the same time, commodities increasingly become part of portfolio allocation, together with stock classes.

At a macroeconomic level, policymakers pay a particular attention to commodity prices and their volatility given their potential to feed inflation pressures. Volatility of commodity prices is thus a central issue for the world economy, as notably illustrated by the G20 which addressed the question of excessive fluctuations and volatility of commodity prices in its September 2009 Pittsburgh summit. Moreover, analyzing the links between commodity and stock markets is of particular interest for financial players as raw materials enter many investment portfolios, together with stock classes (Silvennoinen and Thorp, 2010; Dwyer et al., 2011; Vivian and Wohar, 2012). Furthermore, as documented by Choi and Hammoudeh (2010), commodity traders concurrently look at both stock and commodity markets fluctuations to infer the trend of each market. Comparing the dynamic volatility of raw materials and equities prices provides useful information about possible substitution strategies between commodity and stock classes. In particular, volatility plays a key role regarding hedging possibilities, and impacts asset allocation across raw materials and their risk-return trade-off. Building on the observed links between commodity and stock markets, a recent literature has emerged regarding the impact of investors'

\footnotetext{
${ }^{1}$ We would like to thank Agnès Bénassy-Quéré and Gunther Capelle-Blancard for helpful remarks and suggestions.

*EconomiX-CNRS, University of Paris Ouest, and Ecole Polytechnique, France. E-mail: acretibettoni@u-paris10.fr

${ }^{\dagger}$ EconomiX-CNRS, University of Paris Ouest, France. E-mail: marc.joets@u-paris10.fr

${ }^{\ddagger}$ Corresponding author. EconomiX-CNRS, University of Paris Ouest and CEPII, Paris, France. Address: University of Paris Ouest, 200 avenue de la République, 92001 Nanterre Cedex, France. Phone: +33 (0)1 40975860. Fax: +33 (0)1 409777 84. E-mail: valerie.mignoneu-paris10.fr
} 
Figure 1 - S\&P 500 stock returns volatility (01/03/2001-11/28/2011)

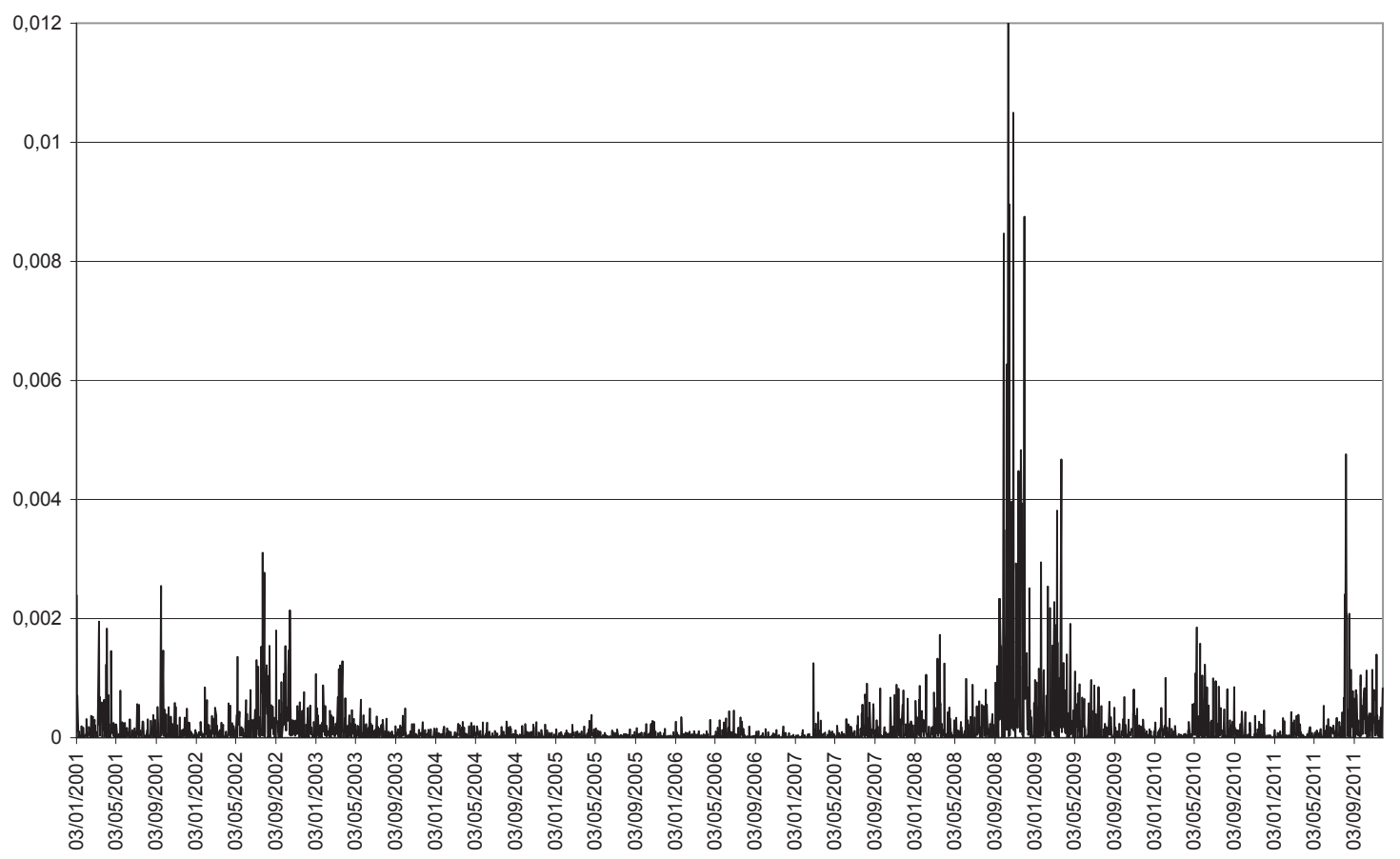

Source: Data are extracted from Datastream. Volatility is proxied by the daily squared returns of prices. 
Figure 2 - Commodity price returns volatility (01/03/2001-11/28/2011)

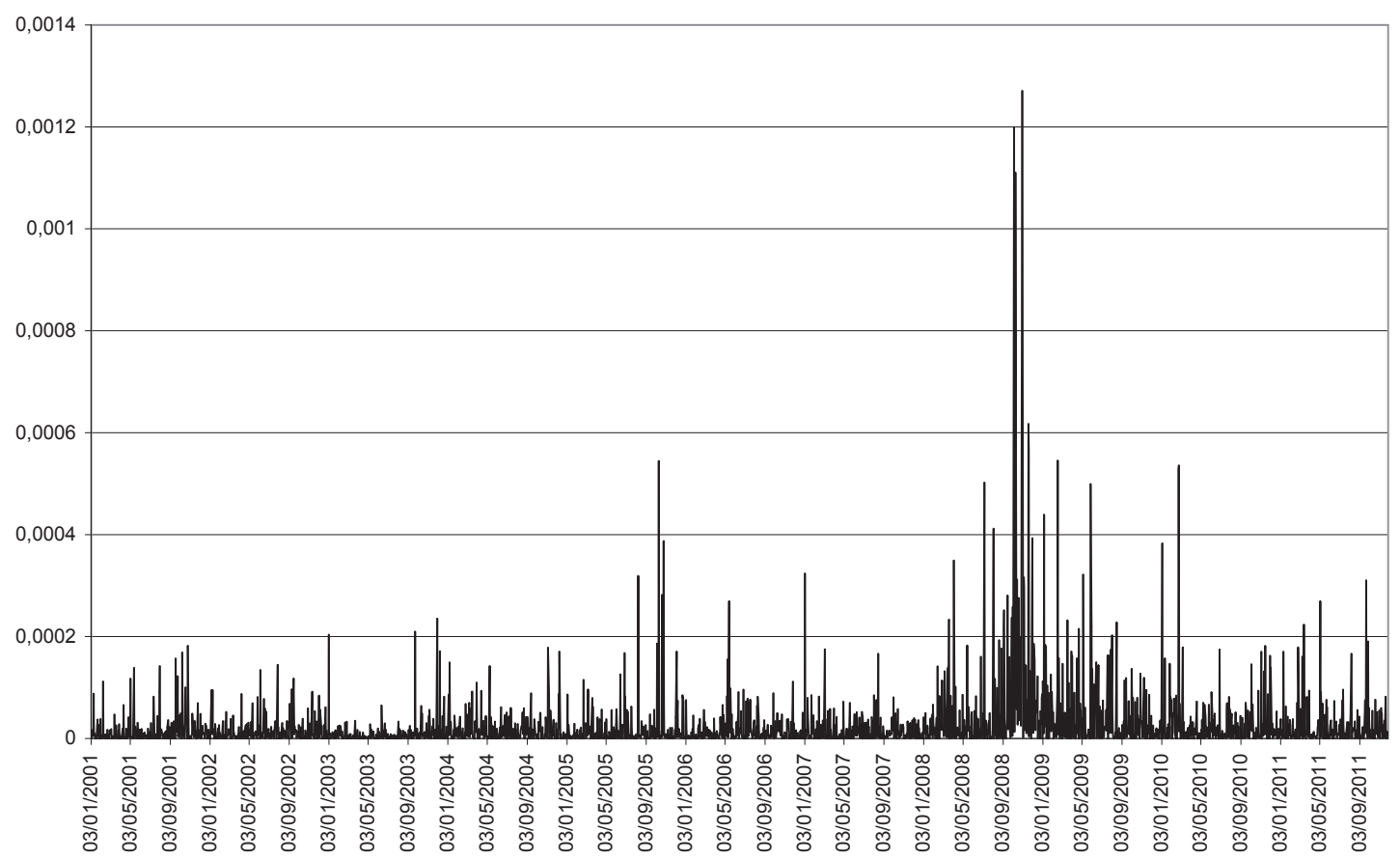

Source: Data are extracted from Datastream. Volatility is proxied by the daily squared returns of prices. 
Figure 3 - Evolution of S\&P 500 and CRB indexes (01/03/2001-11/28/2011)

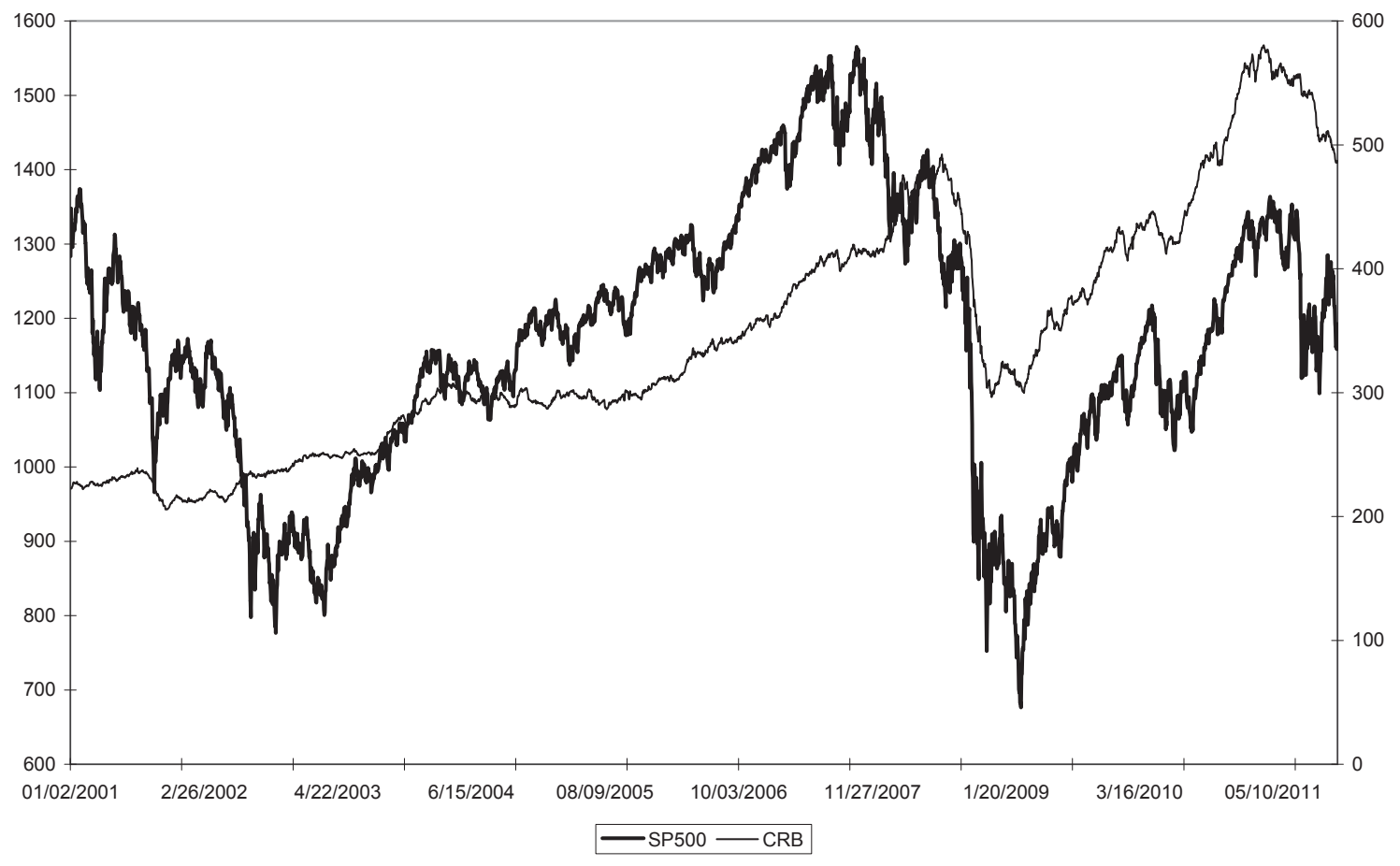

Source: Data are extracted from Datastream. 
behavior in explaining the increase in both level and volatility of commodity prices. ${ }^{2}$ However, as underlined by Vivian and Wohar (2012), no clear-cut conclusion has been reached so far.

In this paper, we contribute to the emerging empirical literature dealing with the relationships between commodity and stock markets. More specifically, we focus on the dynamics of the correlations between both markets, and analyze whether those correlations evolve according to the situation-bullish or bearish-in the stock market. We pay a particular attention to the recent 2007-2008 financial crisis by investigating whether it has strengthened or disrupted the links between stock and commodity markets. From a methodological viewpoint, we follow the dynamic conditional correlation (DCC) GARCH approach introduced by Engle (2002) which allows to assess the changes in correlations between commodity and stock returns over time. The DCC-GARCH approach has been followed by Choi and Hammoudeh (2010) in a quite similar context, but our study considerably extends the analysis. ${ }^{3}$ Our sample consists of 25 commodities covering various sectors over the period from January 3, 2001 to November 28, 2011. Relying on a large panel of raw materials (energy, metals, agricultural, food, ...) allows us to study whether commodities constitute an homogenous asset class with regard to their links with stock markets, and whether the crisis has engendered a financialization of commodity markets. ${ }^{4}$ This kind of relationship has typically been investigated in the case of oil (Doyle et al., 2007; Mouawad, 2009), though the cross-effect on oil and stock market volatility remains globally unclear.

Our results show that correlations between commodity and stock markets are time-varying and highly volatile. The impact of the 2007-2008 financial crisis is noticeable, emphasizing the links between commodity and stock markets, and highlighting the financialization of commodity markets. We also show that, while sharing some common features, commodities cannot be considered a homogeneous asset class: a speculation phenomenon ${ }^{5}$ is for instance highlighted for oil, coffee and cocoa, while the safe-haven role of gold is evidenced.

\footnotetext{
${ }^{2}$ Recent references include Eckaus (2008), Khan (2009), Masters and White (2009), Capelle-Blancard and Coulibaly (2011), Du et al. (2011), Stout (2011), Valiante (2011), Büyükşahin et al. (2008, 2011), Irwin and Sanders (2012), Vivian and Wohar (2012), and Manera et al. (2012) for a review.

${ }^{3}$ Only five commodities were considered in Choi and Hammoudeh (2010), instead of 25 in our case.

${ }^{4}$ The financialization process refers to a situation in which the price of an individual commodity is not only determined by its primary supply and demand, but also by several financial factors and investors' behavior in derivative markets.

${ }^{5}$ We use the term "speculation" for simplifying purposes to refer to a situation in which investors (i) engage in transactions to profit from short-term fluctuations in the market value of the considered asset or product, and (ii) focus only on price movements rather than on the fundamentals linked to the considered asset or product. Empirically, speculation is assessed here through the dynamics of correlations between oil and commodity markets: increasing correlations in times of rising oil prices, and decreasing — and even negative — correlations during periods of declining stock prices.
} 
The rest of the paper is organized as follows. Section 2 briefly reviews the literature about the links between commodity and stock markets. Section 3 presents the data as well as some stylized facts, and Section 4 deals with methodological aspects. Results are displayed in Section 5, and Section 6 concludes the paper.

\section{LiterATURE REVIEW}

As documented in the introduction, commodity markets share several characteristics with stock markets and financial assets. So far the literature has analyzed this phenomenon mainly by focusing on oil, and looking at the comovements between stock and oil markets. Most of this literature offers substantial evidence on the impact of oil on stock prices, putting forward a negative relationship between oil price and stock market returns. ${ }^{6}$ For instance, Jones and Kaul (1996), using a standard cash-flow dividend valuation model, find a significant negative impact of oil price shocks on US and Canadian quarterly stock prices in the postwar period. Several models, relying on some variants of Vector Autoregressive analysis (VAR), highlight similar findings. Park and Ratti (2008), performing a multivariate VAR analysis, find statistically significant impact of oil prices shocks on real stock returns for US and 13 European countries over the period from January 1986 to December 2005. Sadorsky (1999) investigates relationships among monthly oil prices, S\&P 500 stock returns, short-term interest rate, and industrial production for the January 1947-April 1996 period by means of an unrestricted VAR model. The author shows that oil prices and oil price volatility both play important roles in affecting S\&P 500 stock returns. Papapetrou (2001) estimates a vector error-correction model on monthly data for Greece from January 1989 to June 1999, and concludes that oil prices drive stock price dynamics.

Shifting from the study of comovements to volatility analysis, the most recent literature focuses on volatility spillovers between oil/industrial commodity and stock markets. Hammoudeh et al. (2004) investigate the spillover effects, day effects, and dynamic relationships among five daily S\&P oil sector stock indices and five daily oil prices for the US oil markets ${ }^{7}$ from July 17, 1995 to October 10, 2001 using cointegration techniques as well as ARCH-type models. They evidence volatility spillovers from the oil futures market on the stocks of some oil sectors. They also find an oil volatility transmission day effect, Friday having a calming effect on the volatility of oil stocks. Chiou and Lee (2009) examine the asymmetric effects of WTI daily oil prices on S\&P 500 stock returns from January 1, 1992 to November 7, 2006, by investigating structure changes in this dependency relationship. Using the Autoregressive Conditional Jump Intensity model with expected, unexpected and negative unexpected oil price fluctuations, they find that high fluctuations in oil prices have asymmetric unexpected effects on stock returns. Malik and

\footnotetext{
${ }^{6}$ For an extensive review of the literature on this topic, see Filis et al. (2011).

${ }^{7}$ The US oil industry encompasses companies engaged in various phases of oil production and processing. The US oil markets include the West Texas Intermediate (WTI), Cushing spot and the New York Mercantile Exchange (NYMEX) for 1 to 4 month futures prices.
} 
Ewing (2009) rely on bivariate GARCH models to estimate the volatility transmission between weekly WTI oil prices and equity sector returns ${ }^{8}$ from January 1, 1992 to April 30, 2008 and find evidence of spillover mechanisms. Focusing on the Brent market, Filis et al. (2011) analyze time-varying correlations between oil prices and stock markets by differentiating oil-importing (USA, Germany, and the Netherlands) and oil-exporting (Canada, Mexico, and Brazil) countries. Using the multivariate DCC-GARCH approach from January 1988 to September 2009, they find that the conditional variances of oil and stock prices do not differ for oil-importing and oil-exporting economies. However, time-varying correlations depend on the origin of the oil shocks: the response from aggregate demand-side shocks is much greater than supply-side shocks originated by OPEC's production cuts. Finally, Choi and Hammoudeh (2010) extend the time-varying correlations analysis by considering commodity prices of Brent oil, WTI oil, copper, gold and silver, and the S\&P 500 index from January 2, 1990 to May 1, 2006. They show that commodity correlations have increased since 2003 , limiting hedging substitutability in portfolios.

Our study extends the previous literature by considerably enlarging the sample of commodities analyzed. We consider 25 different strategic commodities, traded in the US and covering various sectors: energy, precious metals, agricultural, non-ferrous metals, food, oleaginous, exotic and livestock. The dataset we have built allows us to compare the behavior of each commodity group regarding stock market fluctuations, and to study whether correlations between commodities and equities evolve over time and depend on the situation-bearish or bullish-on the stock market.

\section{DATA AND STYLIZED FACTS}

We consider daily spot price series extracted from Datastream for a large sample of commodities over the January 3, 2001 - November 28, 2011 period. ${ }^{9}$ We investigate 25 different commodities covering the following various sectors: energy, precious metals, agricultural, non-ferrous metals, food, oleaginous, exotic and livestock. All price series are quoted in US dollars. We also consider an aggregate commodity price index, the Commodity Research Bureau (CRB) index. Regarding the equity market, we rely on one of the main US stock market index, namely the S\&P 500 index.

Table 1 in Appendix provides some descriptive statistics regarding the returns series, defined as $r_{t}=\ln \left(P_{t} / P_{t-1}\right)$, where $P_{t}$ denotes the price index at time $t$. The group of energy commodities seems to differ from other groups in terms of volatility: the variance of electricity, gas and to

\footnotetext{
${ }^{8}$ The following sectors are considered: financials, industrials, consumer services, health care, and technology.

${ }^{9}$ An alternative would have been to rely on futures prices. However, as highlighted by Vivian and Wohar (2012), spot prices are the underlying asset upon which derivatives are based, a fact that is important when analyzing volatility. In addition, relying on spot prices avoids issues related to rollover of futures contracts.
} 
a lesser extent oil price returns is higher than that obtained for the other commodities $;{ }^{10}$ being also higher than those of S\&P 500 and CRB returns. The electricity series is extremely volatile, as its high kurtosis value shows. This is not surprising given that electricity is not storable and prices reflect the real-time equilibrium between demand and supply, with contingencies that vary greatly from one day to another. ${ }^{11}$ Together with high volatility, the group of energy commodities exhibits low returns on average, leading to the lowest benefit-risk trade off compared to the S\&P 500 and the CRB indexes, and the group of food and oleaginous commodities which are more profitable on the return-risk basis. Statistics in Table 1 also show that all series are characterized by a time-varying volatility, an ARCH effect being present for almost all returns series. Finally, returns tend to be autocorrelated, especially for the energy and the precious metals groups, indicating some persistence phenomenon.

\section{Methodology}

To investigate the time evolution of correlations between the commodity and stock markets, we rely on the dynamic conditional correlation (DCC) GARCH models introduced by Engle (2002). Let $r_{t}$ be the vector composed of two returns series, $r_{t}=\left(r_{1 t}, r_{2 t}\right)^{\prime}$. Denoting by $A(L)$ the lag polynomial, we have:

$$
A(L) r_{t}=\mu+e_{t}
$$

where $e_{t}$ is the error-term vector.

The DCC model is based on the hypothesis that the conditional returns are normally distributed with zero mean and conditional covariance matrix $H_{t}=E\left[r_{t} r_{t}^{\prime} \mid I_{t-1}\right]$. The covariance matrix is expressed as follows:

$$
H_{t}=D_{t} R_{t} D_{t}
$$

where $D_{t}=\operatorname{diag}\left[\sqrt{h_{1 t}}, \sqrt{h_{2 t}}\right]$ is a diagonal matrix of time-varying standard deviations issued from the estimation of univariate $\operatorname{GARCH}(1,1)$ processes:

\footnotetext{
${ }^{10}$ The increasing trend in volatility of oil and gas market prices in the USA has also been documented by Pindyck (2004) among others.

${ }^{11}$ Though the Commodity Futures Trading Commission provides no data regarding the financialization of electricity (see Table 2 in Appendix), the latter can also be considered as a financial product. An illustration is given by the Nordic financial electricity market, whose liquidity provided by a number of speculators highlights that it is also important for financial trading purposes. More fundamentally, with the creation of electricity spot marketsincluding various standardized products_-pure financial trading has been progressively growing to the point that the Dodd-Frank Act provides that these markets are monitored within the framework of financial stability measures.
} 


$$
h_{t}=\alpha_{0}+\alpha_{1} \varepsilon_{t-1}^{2}+\beta_{1} h_{t-1}
$$

and $R_{t}$ is the conditional correlation matrix of the standardized disturbances $\varepsilon_{t}$, with $\varepsilon_{t}=$ $D_{t}^{-1} r_{t}$ :

$$
R_{t}=\left[\begin{array}{cc}
1 & q_{12 t} \\
q_{21 t} & 1
\end{array}\right]
$$

The matrix $R_{t}$ is decomposed into:

$$
R_{t}=Q_{t}^{*-1} Q_{t} Q_{t}^{*-1}
$$

where $Q_{t}$ is the positive definite matrix containing the conditional variances-covariances of $\varepsilon_{t}$, and $Q_{t}^{*-1}$ is the inverted diagonal matrix with the square root of the diagonal elements of $Q_{t}$ :

$$
Q_{t}^{*-1}=\left[\begin{array}{cc}
1 / \sqrt{q_{11 t}} & 0 \\
0 & 1 / \sqrt{q_{22 t}}
\end{array}\right]
$$

The DCC $(1,1)$ model is then given by:

$$
Q_{t}=\omega+\alpha \varepsilon_{t-1} \varepsilon_{t-1}^{\prime}+\beta Q_{t-1}
$$

where $\omega=(1-\alpha-\beta) \bar{Q}, \bar{Q}$ being the unconditional covariance of the standardized disturbances $\varepsilon_{t}$.

The dynamic conditional correlations are finally given by:

$$
\rho_{12 t}=\frac{q_{12 t}}{\sqrt{q_{11 t} q_{22 t}}}
$$

Note that, following Engle (2002), the estimation of this model is done using a two-step maximum likelihood estimation method, the likelihood function being given by: ${ }^{12}$

$$
L=-\frac{1}{2} \sum_{t=1}^{T}\left(2 \log (2 \pi)+2 \log \left|D_{t}\right|+\log \left|R_{t}\right|+\varepsilon_{t}^{\prime} R_{t}^{-1} \varepsilon_{t}\right)
$$

\footnotetext{
${ }^{12}$ See Engle (2002).
} 


\section{RESUlts}

To assess the evolution of correlations between stock and commodity markets over time, Figures A1 in Appendix report the dynamic conditional correlations between each commodity and the S\&P 500 returns series. The links between markets during periods of financial stress are clearly underlined, ${ }^{13}$ putting forward that investment in equities constitutes an alternative to commodities, providing a mechanism for substitution between asset classes. Although there are some specific features for each type of commodity market (as we will explain in detail below), some common characteristics emerge.

First, correlations are highly volatile throughout the period. For many raw materials, this volatility is particularly marked after the 2007-2008 financial crisis. In all cases, there is an increase in volatility during and following the crisis. Second, in most cases, the largest drop in the correlations appears at the time of the 2008 financial crisis. The stock market collapse has loosened the conditional links between stock and commodity price returns, but only in the very short run. This decrease in correlations during times of high financial markets' stress may be linked to a flight-to-quality phenomenon. When risk market rises, the benefits of diversification are most appreciated and investors tend to choose commodities as refuge instruments. This shortrun characteristic could thus explain the temporary disrupted link between both markets (see Silvennoinen and Thorp, 2010; Chong and Miffre, 2010). Third, for almost all of the series, the highest correlations are observed after the crisis, at the end of the period under study. Both markets move upward during episodes of growing world demand for industrial commodities, giving an important role to commercial traders who use commodity futures to hedge their business activities. On the whole, the 2007-2008 financial crisis has caused significant changes in the relationship between stock and commodity markets, as well as increased correlation in the volatility. Regarding the long-run trends, correlations are likely to be governed by industrialization and financialization processes, as well as by commercial and non-commercial traders.

Let us now look more specifically at the different types of markets, starting by the energy group. Oil is clearly the commodity the most related to the stock market, confirming previous studies focusing on the oil market (Jones and Kaul, 1996; Hammoudeh et al., 2004; Filis et al., 2011; and references in Section 2). This predominance of oil may be due to the fact that it is one of the most important production factors. From a theoretical viewpoint, the fundamental value of any asset is given by its expected discounted cash flows. Consequently, an oil price increase will generate a rise in production costs, leading to restraining profits and, in turn, to a diminution in shareholders' value. In times of rising stock prices, the correlations between stock and oil markets increase. During periods of declining stock prices, correlations tend to decrease and become negative during the 2007-2008 crisis. This is also consistent with the well documented oil

\footnotetext{
${ }^{13}$ The grey bands correspond to periods of bearish stock market, the white stripes corresponding to periods of bullish stock market.
} 
speculation phenomenon, the increase in crude prices being accentuated in times of rising stock market. From this perspective, oil cannot be seen as a means of portfolio diversification. Gas and electricity display a quite similar evolution in terms of dynamic correlations. Correlations tend to increase at the beginning of the period under study and then remain relatively stable, regardless of the situation on the stock market. Correlations are often negative between stock and electricity markets, putting forward that the behavior of the electricity market is mainly driven by its own market fundamentals (i.e. non-storability, inelasticity of the supply,...).

Turning to the precious metals group, gold is different from the other commodities. Indeed, correlations are mostly negative and diminish in times of declining stock prices, highlighting adverse evolution in the markets. This is consistent with a safe-haven role of gold (see for instance Baur et al., 2010). For the other precious metals, the dynamics are relatively close, with increased correlations' volatility after the 2007-2008 crisis followed by a rise in correlations until mid-2010.

The group of exotic commodities also displays an interesting pattern. While the dynamics of correlations for sugar has no particular link with the US stock market trends, coffee and cocoa show a specific profile. As for oil, the correlations tend to grow in times of rising stock prices, and to diminish in periods of declining equity prices. This is in line with a speculation phenomenon in these commodities (see also Gilbert and Morgan, 2010).

Regarding the other groups, two main findings can be highlighted: (i) volatility evolves over time, being quite stable before the 2007-2008 crisis and becoming relatively high during the financial turmoil, and (ii) correlations tend to rise during the crisis, showing increased links between stock and commodity markets.

On the whole, our results show that the 2007-2008 crisis has played a key role in the evolution of the links between stock and commodity markets. Indeed, higher correlations between both markets are generally observed during the financial turmoil, reflecting the phenomenon of financialization of commodity markets that starts to be documented by the literature (see Tang and Xiong, 2010; Silvennoinen and Thorp, 2010). This growing financialization of commodities can be illustrated by the notional values provided by the Commodity Futures Trading Commission (CFTC): as shown in Table 2 in Appendix, these notional values - and especially short nominal values-have increased for all products between 2007 and 2011. This phenomenon is particularly noticeable for oil, a result which is consistent with the fact that it is the most financiarized commodity according to the CFTC - the long and short notional values being respectively estimated at \$69.4bn and \$26.7bn at the end of November 2011 (see Table 2 in Appendix). In addition, our findings show that raw materials cannot be aggregated in an homogeneous asset class: they are certainly influenced by common macroeconomic factors but also by their own 
market determinants.

To complement these figures, Tables 3 to 7 in Appendix report the estimation results of DCCGARCH $(1,1)$ models for the whole period, as well as for four sub-periods: (i) two bearish stock market sub-periods: January 3, 2001-March 11, 2003 and October 13, 2007-March 6, 2009, and (ii) two bullish stock market sub-periods: March 12, 2003-October 12, 2007 and March 7, 2009-November 28, 2011. Looking at the sum of the coefficients $\alpha+\beta$ (see Equation (7)), our results show that volatility is highly persistent given that this sum is very close to 1 for the majority of commodity series. While being high for all considered periods, persistence tends to be higher during the second, bullish stock market sub-period for 12 commodities, including all precious metals. This result illustrates that the persistence of volatility goes along with the financialization of commodities.

\section{Conclusion}

This paper investigates the links between commodity and stock markets. To this end, we rely on the dynamic conditional correlation (DCC) GARCH methodology to establish whether the correlations between both markets evolve over time and depend on the situation-bearish or bullish—on the stock market.

Our main findings can be summarized as follows. In our panel of 25 commodities over the period from January 2001 to November 2011, first, the correlations between commodity and stock returns evolve through time, being highly volatile, particularly since the 2007-2008 financial crisis. While the stock market collapse has loosened the links between both markets on the very short run, the highest correlations are observed during the financial turmoil, showing increased links between stock and commodity markets. Second, some commodities are characterized by a speculation phenomenon, especially oil, coffee and cocoa: while their correlations with S\&P 500 returns grow in times of increasing stock prices, they diminish in times of bearish financial markets. Third, the safe-haven role of gold is evidenced, as its correlations with stock returns are mostly negative and diminish in times of declining stock prices. Fourth, while sharing some common features, commodities can not be considered as an homogeneous asset class.

On the whole, our findings show that the 2007-2008 financial crisis has played a key role, emphasizing the links between commodity and stock markets, and highlighting the financialization of commodity markets. This evolution in commodity and stock correlations reduces their potential substitutability in portfolios. At the idiosyncratic level, the main exceptions are gold, coffee and cocoa for which risk management strategies are possible, with increased risk diversification allowed by their adverse evolution compared to the stock market in times of declining equity prices. 


\section{REFERENCES}

Bai, J., Perron, P. (2003), Computation and Analysis of Multiple Structural Change Models, Journal of Applied Econometrics 18, 1-22.

Baur, D.G., McDermott, T.K. (2010), Is gold a safe haven? International evidence, Journal of Banking and Finance 34(8), 1886-1898.

Büyükşahin, B., Haigh, M.S., Robe, M.A. (2008), Commodities and equities: a 'Market of One'? CFTC Working Paper.

Büyükşahin, B., Harris, J.H. (2011), Do speculators drive crude oil futures prices?, The Energy Journal 32(2), 167-202.

Capelle-Blancard, G., Coulibaly, D. (2011), Index trading and agricultural commodity prices: A panel Granger causality analysis, International Economics 126-127.

Chiou, J.S., Lee, Y.H. (2009), Jump dynamics and volatility: Oil and the stock markets, Energy 34(6), 788-796.

Choi, K., Hammoudeh, S. (2010), Volatility behavior of oil, industrial commodity and stock markets in a regime-switching environment, Energy Policy 38(8), 4388-4399.

Chong, J., Miffre, J. (2010), Conditional correlation and volatility in commodity futures and traditional asset markets, Journal of Alternative Investments 12(3), 61-75.

Doyle, E., Hill, J., Jack, I. (2007), Growth in commodity investment: risk and challenges for commodity market participants, Financial Services Authority (FSA) Report, FSA Markets Infrastructure Department.

Du, X., Yu, C.L., Hayes, D.J. (2011), Speculation and volatility spillover in the crude oil and agricultural commodity markets: A Bayesian analysis, Energy Economics 33, 497-503.

Dwyer, A., Gardner, G., Williams, T. (2011), Global commodity markets-Price volatility and financialisation, Reserve Bank of Australia Bulletin, June.

Eckaus, R.S. (2008), The Oil Price Really Is A Speculative Bubble, Center for Energy and Environmental Policy Research 08-007.

Engle, R.F. (2002), Dynamic Conditional Correlation - A Simple Class of Multivariate GARCH Models, Journal of Business and Economic Statistics 20(3), 339-350. 
Filis, G., Degiannakis, S., Floros, C. (2011), Dynamic correlation between stock market and oil prices: The case of oil-importing and oil-exporting countries, International Review of Financial Analysis 20(3), 152-164.

Gilbert, C.L., Morgan, C.W. (2010), Has food price volatility risen?, Working Paper, Università di Trento, 2/2010.

Hammoudeh, S., Dibooglu, S., Aleisa, E. (2004), Relationships among U.S. oil prices and oil industry equity indices, International Review of Economics and Finance 13(4), 427-453.

Irwin, S.H., Sanders, D.R. (2012), Testing the masters hypothesis in commodity futures markets, Energy Economics 34, 256-269.

Jones, C.M., Kaul, G. (1996), Oil and the stock markets, Journal of Finance 51, 463-491.

Khan, M.S. (2009), The 2008 oil price 'bubble', Peterson Institute for International Economics, PB09-19.

Malik, F., Ewing, B.T. (2009), Volatility transmission between oil prices and equity sector returns, International Review of Financial Analysis 18, 95-100.

Manera, M., Nicolini, M., Vignati, I. (2012), Returns in commodities futures markets and financial speculation: A multivariate GARCH approach, Fondazione Eni Enrico Mattei, 23.2012.

Masters, M.W., White, A.K. (2009), The 2008 commodities bubble: assessing the damage to the United States and its Citizens, Unpublished report, http://media.mcclatchydc.com/smedia/2009/ 05/20/16/Hall-2008-Commodities.source.prod affiliate.91.pdf.

Mouawad, J. (2009), One year after oil's price peak volatility, New York Times, July 10th 2009.

Papapetrou, E. (2001), Oil price shocks, stock market, economic activity and employment in Greece, Energy Economics 23(5), 511-532.

Park, J., Ratti, R.A. (2008), Oil Price Shocks and Stock Markets in the U.S. and 13 European Countries, Energy Economics 30, 2587-2608.

Pindyck, R. (2004), Volatility in Natural Gas and Oil Markets, The Journal of Energy and Development 30(1).

Sadorsky, P. (1999), Oil price shocks and stock market activity, Energy Economics 21, 449-469.

Silvennoinen, A., Thorp, S. (2010), Financialization, Crisis and Commodity Correlation Dynamics, University of Sydney, Quantitative Research Finance Center, Research Paper 267. 
Stout, L.A. (2011), Risk, speculation, and OTC derivatives: an inaugural essay for convivium, Accounting, Economics, and Law 1(1), Article 2.

Tang, K., Xiong, W. (2010), Index Investment and Financialization of Commodities, Princeton University and NBER Working Paper.

Valiante, D. (2011), Commodity Price Formation in Boom-and-Bust Cycles, ECMI Commentaries No. 29, June. http://www.ceps.eu/book/commodity-price-formation-boom-and-bust-cycles.

Vivian, A., Wohar, M.E. (2012), Commodity volatility breaks, Journal of International Financial Markets, Institutions and Money 22, 395-422. 
Table 1 - Summary statistics (whole sample)

\begin{tabular}{|c|c|c|c|c|c|c|c|}
\hline & Mean & S. dev. & Var & Kurtosis & Skewness & LB test & ARCH test \\
\hline \multicolumn{8}{|l|}{ Energy group } \\
\hline Oil & 0.0004 & 0.025 & 0.0006 & 8.29 & 0.01 & $56.77(0.00)$ & $299.7(0.00)$ \\
\hline Gas & -0.0004 & 0.043 & 0.0019 & 9.62 & 0.34 & $155.0(0.00)$ & $325.1(0.00)$ \\
\hline Electricity & -0.0002 & 0.112 & 0.0126 & 16.75 & 0.12 & $138.0(0.00)$ & $159.7(0.00)$ \\
\hline \multicolumn{8}{|c|}{ Precious Metals group } \\
\hline Gold & 0.0006 & 0.011 & 0.0001 & 7.10 & -0.34 & $68.55(0.00)$ & $122.7(0.00)$ \\
\hline Silver & 0.0006 & 0.022 & 0.0005 & 12.27 & -0.57 & $30.23(0.40)$ & $241.2(0.00)$ \\
\hline Platinium & 0.0002 & 0.015 & 0.0002 & 16.61 & -0.48 & $58.76(0.00)$ & $137.4(0.00)$ \\
\hline Palladium & -0.0001 & 0.023 & 0.0005 & 7.91 & -0.36 & $53.96(0.00)$ & $79.26(0.00)$ \\
\hline \multicolumn{8}{|l|}{ Agricultural group } \\
\hline Cotton & 0.0001 & 0.021 & 0.0004 & 15.74 & -0.58 & $35.33(0.23)$ & $0.48(0.48)$ \\
\hline Lumber & $4.66 \mathrm{E}-05$ & 0.021 & 0.0004 & 5.95 & 0.75 & $33.99(0.28)$ & $8.96(0.00)$ \\
\hline \multicolumn{8}{|c|}{ Non-ferrous Metals group } \\
\hline Aluminium & 8.74E-05 & 0.014 & 0.0002 & 5.34 & -0.33 & $26.28(0.61)$ & $98.85(0.00)$ \\
\hline Copper & 0.0005 & 0.019 & 0.0003 & 6.66 & -0.15 & $44.43(0.03)$ & $408.9(0.00)$ \\
\hline Zinc & 0.0002 & 0.021 & 0.0004 & 5.24 & -0.23 & $32.71(0.33)$ & $220.6(0.00)$ \\
\hline Tin & 0.0004 & 0.019 & 0.0003 & 8.65 & -0.24 & $32.22(0.35)$ & $156.64(0.00)$ \\
\hline Lead & 0.0005 & 0.023 & 0.0005 & 5.68 & -0.22 & $30.14(0.45)$ & $100.4(0.00)$ \\
\hline Nickel & 0.0003 & 0.026 & 0.0006 & 6.08 & -0.11 & $25.69(0.69)$ & $193.2(0.00)$ \\
\hline \multicolumn{8}{|l|}{ Food group } \\
\hline Corn & 0.0003 & 0.019 & 0.0003 & 5.39 & 0.17 & $61.33(0.00)$ & $59.09(0.00)$ \\
\hline Wheat & 0.0003 & 0.021 & 0.0004 & 5.20 & 0.17 & $44.59(0.04)$ & $64.03(0.00)$ \\
\hline \multicolumn{8}{|l|}{ Oleaginous group } \\
\hline Palm oil & 0.0004 & 0.020 & 0.0004 & 9.94 & 0.44 & $69.22(0.00)$ & $39.99(0.00)$ \\
\hline Soybean oil & 0.0004 & 0.016 & 0.0002 & 5.14 & 0.13 & $28.41(0.54)$ & $108.4(0.00)$ \\
\hline \multicolumn{8}{|l|}{ Exotic group } \\
\hline Cocoa & 0.0003 & 0.020 & 0.0004 & 5.83 & -0.30 & $43.89(0.04)$ & $2.14(0.14)$ \\
\hline Coffee & 0.0004 & 0.020 & 0.0004 & 5.76 & -0.23 & $47.33(0.02)$ & $31.38(0.00)$ \\
\hline Sugar & $6.34 \mathrm{E}-06$ & 0.023 & 0.0005 & 7.55 & -0.63 & $30.97(0.41)$ & $88.63(0.00)$ \\
\hline \multicolumn{8}{|l|}{ Livestock group } \\
\hline Lean hogs & 0.0001 & 0.020 & 0.0004 & 25.68 & 0.43 & $11.98(0.99)$ & $0.14(0.70)$ \\
\hline Feeder cattle & 0.0001 & 0.009 & 8.64E-05 & 6.54 & -0.35 & $54.60(0.00)$ & $72.59(0.00)$ \\
\hline Live cattle & 0.0001 & 0.010 & 0.0001 & 8.81 & 0.12 & $52.02(0.00)$ & $20.83(0.00)$ \\
\hline Standard \& Poor's & $-7.05 \mathrm{E}-06$ & 0.013 & 220.0001 & 10.98 & -0.16 & $59.56(0.00)$ & $786.8(0.00)$ \\
\hline CRB index & 0.0002 & 0.004 & $2.50 \mathrm{E}-05$ & 8.05 & -0.60 & $125.1(0.00)$ & $239.8(0.00)$ \\
\hline
\end{tabular}

Notes: Between parentheses: p-values. Ljung-Box statistics correspond to a test of the null of no autocorrelation with $r=30$. ARCH Lagrange multiplier statistics correspond to a test of the null of no ARCH effect. 
Table 2 - Index investment data: notional values (in Billions U.S. dollars)

\begin{tabular}{l|cccc}
\hline \hline & \multicolumn{2}{|c}{ December 31, 2007 } & \multicolumn{2}{c}{ November 30, 2011 } \\
& Long & Short & Long & Short \\
\hline Oil (WTI) & 46.7 & 7.0 & 69.4 & 26.7 \\
Gas & 13.2 & 1.8 & 16.2 & 4.1 \\
Gold & 8.4 & 1.1 & 30.0 & 9.5 \\
Silver & 2.4 & 0.3 & 6.9 & 1.6 \\
Cotton & 3.2 & 0.6 & 4.3 & 1.5 \\
Copper & 3.1 & 0.3 & 7.9 & 2.2 \\
Corn & 9.5 & 1.9 & 19.2 & 7.2 \\
Wheat & 10.2 & 2.1 & 10.7 & 4.8 \\
Soybean oil & 2.5 & 0.3 & 4.0 & 1.3 \\
Cocoa & 0.5 & 0.1 & 1.1 & 0.4 \\
Coffee & 2.8 & 0.6 & 5.3 & 2.0 \\
Sugar & 3.9 & 0.7 & 8.4 & 2.4 \\
Lean hogs & 3.0 & 0.9 & 5.2 & 1.7 \\
Feeder cattle & 0.6 & 0.1 & 0.8 & 0.2 \\
Live cattle & 5.9 & 1.3 & 9.1 & 2.9 \\
\hline \hline
\end{tabular}

Notes: Source: CFTC, http://www.cftc.gov/MarketReports/IndexInvestmentData/index.htm. Short (resp. long): denotes the gross short (resp. long) notional value and refers to the case where investors are short (resp. long) a commodity index. 
Table 3 - Estimation results of DCC-GARCH(1,1) models (whole sample)

\begin{tabular}{|c|c|c|c|c|c|}
\hline & Oil & Gas & Elec & Gold & Silver \\
\hline$\mu$ & $8.2 \mathrm{e}-04(3.6 \mathrm{e}-04)^{*}$ & $-7.2 \mathrm{e}-04(5.5 \mathrm{e}-04)$ & $2.7 \mathrm{e}-03(1.2 \mathrm{e}-03)^{*}$ & $5.3 \mathrm{e}-04(1.5 \mathrm{e}-04)^{*}$ & $3.8 \mathrm{e}-04(2.3 \mathrm{e}-04)$ \\
\hline$\omega$ & $1.2 \mathrm{e}-05(6.9 \mathrm{e}-07)^{*}$ & $3.1 \mathrm{e}-05(2.5 \mathrm{e}-06)^{*}$ & $1.0 \mathrm{e}-03(2.2 \mathrm{e}-05)^{*}$ & $1.8 \mathrm{e}-06(7.8 \mathrm{e}-08)^{*}$ & $5.1 \mathrm{e}-06(4.3 \mathrm{e}-07)^{*}$ \\
\hline$\alpha$ & $0.061(1.6 \mathrm{e}-03)^{*}$ & $0.111(2.4 \mathrm{e}-03)^{*}$ & $0.230(4.7 \mathrm{e}-03)^{*}$ & $0.042(9.9 \mathrm{e}-04)^{*}$ & $0.088(1.4 \mathrm{e}-03)^{*}$ \\
\hline$\beta$ & $0.917(1.5 \mathrm{e}-03)^{*}$ & $0.876(1.9 \mathrm{e}-03)^{*}$ & $0.683(3.2 \mathrm{e}-03)^{*}$ & $0.943(7.8 \mathrm{e}-04)^{*}$ & $0.906(1.2 \mathrm{e}-03)^{*}$ \\
\hline \multirow[t]{2}{*}{$\alpha+\beta$} & 0.978 & 0.987 & 0.913 & 0.985 & 0.994 \\
\hline & Platinum & Palladium & Cotton & Lumber & Aluminium \\
\hline$\mu$ & $-3.6 \mathrm{e}-04(1.6 \mathrm{e}-04)^{*}$ & $7.2 \mathrm{e}-05(2.4 \mathrm{e}-04)$ & $3.0 \mathrm{e}-04(3.0 \mathrm{e}-04)$ & $1.8 \mathrm{e}-04(3.5 \mathrm{e}-04)$ & $4.5 \mathrm{e}-05(2.0 \mathrm{e}-05)^{*}$ \\
\hline$\omega$ & $4.1 \mathrm{e}-06(2.3 \mathrm{e}-07)^{*}$ & $1.7 \mathrm{e}-05(3.1 \mathrm{e}-07)^{*}$ & $8.0 \mathrm{e}-06(3.5 \mathrm{e}-07)^{*}$ & $1.1 \mathrm{e}-06(1.0 \mathrm{e}-07)^{*}$ & $1.3 \mathrm{e}-06(1.0 \mathrm{e}-07)^{*}$ \\
\hline$\alpha$ & $0.107(1.7 \mathrm{e}-03)^{*}$ & $0.079(1.4 \mathrm{e}-03)^{*}$ & $0.054(7.8 \mathrm{e}-04)^{*}$ & $0.010(2.2 \mathrm{e}-04)^{*}$ & $0.033(5.7 \mathrm{e}-04)^{*}$ \\
\hline$\beta$ & $0.879(1.4 \mathrm{e}-03)^{*}$ & $0.889(9.4 \mathrm{e}-04)^{*}$ & $0.931(6.4 \mathrm{e}-04)^{*}$ & $0.987(2.0 \mathrm{e}-04)^{*}$ & $0.960(4.9 \mathrm{e}-04)^{*}$ \\
\hline \multirow[t]{2}{*}{$\alpha+\beta$} & 0.986 & 0.968 & 0.985 & 0.997 & 0.993 \\
\hline & Copper & Zinc & Tin & Lead & Nickel \\
\hline$\mu$ & $4.7 \mathrm{e}-04(1.5 \mathrm{e}-04)^{*}$ & $1.5 \mathrm{e}-04(1.8 \mathrm{e}-04)$ & $5.3 \mathrm{e}-04(2.3 \mathrm{e}-04)^{*}$ & $3.9 \mathrm{e}-04(2.5 \mathrm{e}-04)$ & $4.5 \mathrm{e}-04(3.0 \mathrm{e}-04)$ \\
\hline$\omega$ & $3.5 \mathrm{e}-06(2.2 \mathrm{e}-07)^{*}$ & $2.5 \mathrm{e}-06(1.9 \mathrm{e}-07)^{*}$ & $1.4 \mathrm{e}-05(4.0 \mathrm{e}-07)^{*}$ & $5.1 \mathrm{e}-06(2.6 \mathrm{e}-07)^{*}$ & $1.0 \mathrm{e}-05(5.7 \mathrm{e}-07)^{*}$ \\
\hline$\alpha$ & $0.047(8.8 \mathrm{e}-04)^{*}$ & $0.037(6.8 \mathrm{e}-04)^{*}$ & $0.109(0.002)^{*}$ & $0.038(7.8 \mathrm{e}-04)^{*}$ & $0.046(0.001)^{*}$ \\
\hline$\beta$ & $0.941(8.1 \mathrm{e}-04)^{*}$ & $0.956(5.9 \mathrm{e}-04)^{*}$ & $0.856(0.001)^{*}$ & $0.951(6.5 \mathrm{e}-04)^{*}$ & $0.936(9.7 \mathrm{e}-04)^{*}$ \\
\hline \multirow[t]{2}{*}{$\alpha+\beta$} & 0.988 & 0.993 & 0.965 & 0.989 & 0.982 \\
\hline & Corn & Wheat & Palm oil & Soybean oil & Cocoa \\
\hline$\mu$ & $6.3 \mathrm{e}-04(1.4 \mathrm{e}-04)^{*}$ & $4.5 \mathrm{e}-04(2.8 \mathrm{e}-04)$ & $7.2 \mathrm{e}-04(2.9 \mathrm{e}-04)^{*}$ & 7.1e-04 (2.5e-04) & $2.9 \mathrm{e}-04(3.3 \mathrm{e}-04)$ \\
\hline$\omega$ & $5.1 \mathrm{e}-06(2.3 \mathrm{e}-07)^{*}$ & 5.0e-06 (3.8e-07)* & $5.9 \mathrm{e}-06(2.1 \mathrm{e}-07)^{*}$ & $3.8 \mathrm{e}-06(2.1 \mathrm{e}-07)^{*}$ & $3.4 \mathrm{e}-06(1.6 \mathrm{e}-07)^{*}$ \\
\hline$\alpha$ & $0.038(8.9 \mathrm{e}-04)^{*}$ & $0.039(9.5 \mathrm{e}-04)^{*}$ & $0.063(1.1 \mathrm{e}-03)^{*}$ & $0.035(1.0 \mathrm{e}-03)^{*}$ & $0.017(4.4 \mathrm{e}-04)^{*}$ \\
\hline$\beta$ & $0.947(7.0 \mathrm{e}-04)^{*}$ & $0.949(8.8 \mathrm{e}-04)^{*}$ & $0.923(8.0 \mathrm{e}-04)^{*}$ & $0.948(9.1 \mathrm{e}-04)^{*}$ & $0.974(4.0 \mathrm{e}-04)^{*}$ \\
\hline \multirow[t]{2}{*}{$\alpha+\beta$} & 0.985 & 0.985 & 0.986 & 0.983 & 0.991 \\
\hline & Coffee & Sugar & Lean & Feeder & Live \\
\hline$\mu$ & $5.0 \mathrm{e}-04(3.4 \mathrm{e}-04)$ & $2.1 \mathrm{e}-04(3.7 \mathrm{e}-04)$ & $1.6 \mathrm{e}-04(3.7 \mathrm{e}-04)$ & $1.5 \mathrm{e}-04(1.2 \mathrm{e}-04)$ & 2.0e-04 (2.0e-04) \\
\hline$\omega$ & $2.1 \mathrm{e}-06(1.4 \mathrm{e}-07)^{*}$ & $1.0 \mathrm{e}-05(6.2 \mathrm{e}-07)^{*}$ & $8.6 \mathrm{e}-05(6.5 \mathrm{e}-07)^{*}$ & $1.0 \mathrm{e}-06(3.5 \mathrm{e}-08)^{*}$ & $1.2 \mathrm{e}-06(1.7 \mathrm{e}-06)^{*}$ \\
\hline$\alpha$ & $0.013(3.2 \mathrm{e}-04)^{*}$ & $0.059(0.001)^{*}$ & $-4.0 \mathrm{e}-03(1.4 \mathrm{e}-03)^{*}$ & $0.012(3.3 \mathrm{e}-04)^{*}$ & $0.062(8.6 e-03)^{*}$ \\
\hline$\beta$ & $0.981(3.1 \mathrm{e}-03)^{*}$ & $0.923(0.001)^{*}$ & $0.804(1.4 \mathrm{e}-03)^{*}$ & $0.975(2.8 \mathrm{e}-04)^{*}$ & $0.164(0.015)^{*}$ \\
\hline$\alpha+\beta$ & 0.994 & 0.982 & 0.808 & 0.987 & 0.226 \\
\hline
\end{tabular}

Notes: Standard errors are in parentheses.* denotes rejection of the null hypothesis at $1 \%, 5 \%$ or $10 \%$ significance level. 
Table 4 - Estimation results of DCC-GARCH(1,1) models (sample period: 2001/01/032003/03/11)

\begin{tabular}{|c|c|c|c|c|c|}
\hline & Oil & Gas & Elec & Gold & Silver \\
\hline$\mu$ & $9.5 e-04(9.5 e-04)$ & $1.8 \mathrm{e}-04(1.4 \mathrm{e}-04)$ & 7.8e-04 (3.1e-03) & $6.2 \mathrm{e}-04(2.4 \mathrm{e}-04)^{*}$ & $1.1 \mathrm{e}-04(3.7 \mathrm{e}-04)$ \\
\hline$\omega$ & $5.7 \mathrm{e}-05(4.2 \mathrm{e}-06)^{*}$ & $2.5 \mathrm{e}-04(2.1 \mathrm{e}-05)^{*}$ & $6.3 \mathrm{e}-04(3.3 \mathrm{e}-05)^{*}$ & $2.4 \mathrm{e}-05(8.9 \mathrm{e}-07)^{*}$ & $3.4 \mathrm{e}-05(1.9 \mathrm{e}-06)^{*}$ \\
\hline$\alpha$ & $0.095(6.4 \mathrm{e}-03)^{*}$ & $0.214(0.014)^{*}$ & $0.250(0.011)^{*}$ & $0.221(0.017)^{*}$ & $0.133(0.019)^{*}$ \\
\hline$\beta$ & $0.816(6.9 \mathrm{e}-03)^{*}$ & $0.689(0.011)^{*}$ & $0.740(4.6 \mathrm{e}-03)^{*}$ & $0.442(0.018)^{*}$ & $0.583(0.018)^{*}$ \\
\hline \multirow[t]{2}{*}{$\alpha+\beta$} & 0.911 & 0.903 & 0.990 & 0.663 & 0.716 \\
\hline & Platinum & Palladium & Cotton & Lumber & Aluminium \\
\hline$\mu$ & $6.4 \mathrm{e}-04(4.1 \mathrm{e}-04)^{*}$ & $-2.0 \mathrm{e}-03(6.9 \mathrm{e}-04)^{*}$ & $4.0 \mathrm{e}-05(2.2 \mathrm{e}-05)^{*}$ & $1.2 \mathrm{e}-04(0.0007)$ & $-3.8 \mathrm{e}-04(2.0 \mathrm{e}-04)$ \\
\hline$\omega$ & $1.4 \mathrm{e}-05(7.5 \mathrm{e}-07)^{*}$ & $1.5 \mathrm{e}-04(3.7 \mathrm{e}-06)^{*}$ & $-2.0(1.0 \mathrm{e}-06)^{*}$ & $4.5 \mathrm{e}-04(1.2 \mathrm{e}-05)^{*}$ & $2.1 \mathrm{e}-04(1.0 \mathrm{e}-06)^{*}$ \\
\hline$\alpha$ & $0.118(7.5 e-03)^{*}$ & $0.160(0.019)^{*}$ & $-9.1 \mathrm{e}-03(1.0 \mathrm{e}-06)^{*}$ & $0.116(0.053)^{*}$ & $0.037(0.002)^{*}$ \\
\hline$\beta$ & $0.805(6.7 \mathrm{e}-03)^{*}$ & $0.508(0.010)^{*}$ & $0.900(1.0 \mathrm{e}-04)^{*}$ & $0.080(0.066)$ & $0.942(0.002)^{*}$ \\
\hline \multirow[t]{2}{*}{$\alpha+\beta$} & 0.923 & 0.668 & 0.909 & 0.196 & 0.979 \\
\hline & Copper & Zinc & Tin & Lead & Nickel \\
\hline$\mu$ & $-1.1 \mathrm{e}-04(2.2 \mathrm{e}-04)$ & $-4.5 e-04(3.7 e-04)$ & $-7.6 e-05(4.4 e-04)$ & $-1.5 e-04(4.4 e-04)$ & $-1.1 \mathrm{e}-04(7.4 \mathrm{e}-04)$ \\
\hline$\omega$ & $2.8 \mathrm{e}-05(1.0 \mathrm{e}-06)^{*}$ & $9.5 \mathrm{e}-05(4.4 \mathrm{e}-04)^{*}$ & $1.2 \mathrm{e}-05(1.4 \mathrm{e}-04)^{*}$ & $3.6 \mathrm{e}-06(1.0 \mathrm{e}-06)^{*}$ & $8.8 \mathrm{e}-06(5.5 \mathrm{e}-07)^{*}$ \\
\hline$\alpha$ & $0.004(8.0 \mathrm{e}-04)^{*}$ & $0.183(0.045)^{*}$ & $0.105(0.008)^{*}$ & $0.022(0.001)^{*}$ & $0.011(8.1 \mathrm{e}-04)^{*}$ \\
\hline$\beta$ & $0.976(8.0 \mathrm{e}-04)^{*}$ & $0.081(0.033)^{*}$ & $0.779(0.006)^{*}$ & $0.957(0.001)^{*}$ & $0.963(1.3 \mathrm{e}-03)^{*}$ \\
\hline \multirow[t]{2}{*}{$\alpha+\beta$} & 0.980 & 0.264 & 0.884 & 0.979 & 0.974 \\
\hline & Corn & Wheat & Palm oil & Soybean oil & Cocoa \\
\hline$\mu$ & $2.4 \mathrm{e}-04(5.6 \mathrm{e}-04)$ & $8.0 \mathrm{e}-05(4.9 \mathrm{e}-04)$ & $3.5 \mathrm{e}-04(6.4 \mathrm{e}-04)$ & $5.0 \mathrm{e}-04(4.9 \mathrm{e}-04)$ & $2.0 \mathrm{e}-03(9.0 \mathrm{e}-04)$ \\
\hline$\omega$ & $6.1 \mathrm{e}-06(4.4 \mathrm{e}-07)^{*}$ & $2.3 \mathrm{e}-06(2.3 \mathrm{e}-07)^{*}$ & $1.3 \mathrm{e}-07(2.5 \mathrm{e}-07)$ & $1.3 \mathrm{e}-05(8.8 \mathrm{e}-07)^{*}$ & $4.7 \mathrm{e}-05(3.2 \mathrm{e}-06)^{*}$ \\
\hline$\alpha$ & $0.026(2.4 \mathrm{e}-03)^{*}$ & $6.8 \mathrm{e}-03(6.6 \mathrm{e}-04)^{*}$ & $0.010(4.1 \mathrm{e}-04)^{*}$ & $0.024(4.6 \mathrm{e}-03)^{*}$ & $0.063(6.9 \mathrm{e}-03)^{*}$ \\
\hline$\beta$ & $0.941(2.2 \mathrm{e}-03)^{*}$ & $0.983(7.8 \mathrm{e}-04)^{*}$ & $0.983(5.6 \mathrm{e}-04)^{*}$ & $0.905(4.5 \mathrm{e}-03)^{*}$ & $0.844(6.8 \mathrm{e}-03)^{*}$ \\
\hline \multirow[t]{2}{*}{$\alpha+\beta$} & 0.967 & 0.989 & 0.993 & 0.929 & 0.907 \\
\hline & Coffee & Sugar & Lean & Feeder & Live \\
\hline$\mu$ & $3.3 e-04(1.0 \mathrm{e}-03)$ & $-4.6 e-04(8.1 e-04)$ & $-3.7 e-04(0.001)$ & $-4.0 \mathrm{e}-04(2.1 \mathrm{e}-04)$ & $6.7 \mathrm{e}-05(1.2 \mathrm{e}-04)$ \\
\hline$\omega$ & $9.6 \mathrm{e}-05(4.6 \mathrm{e}-06)^{*}$ & $3.9 \mathrm{e}-04(2.0 \mathrm{e}-05)^{*}$ & $9.6 \mathrm{e}-05(1.5 \mathrm{e}-06)^{*}$ & $4.4 \mathrm{e}-06(3.3 \mathrm{e}-08)^{*}$ & $4.4 \mathrm{e}-07(3.3 \mathrm{e}-09)^{*}$ \\
\hline$\alpha$ & $0.033(7.5 \mathrm{e}-03)^{*}$ & $0.226(0.032)^{*}$ & $0.006(0.002)^{*}$ & $0.067(0.006)^{*}$ & $0.011(1.4 \mathrm{e}-05)^{*}$ \\
\hline$\beta$ & $0.817(7.4 \mathrm{e}-03)^{*}$ & $0.014(0.035)$ & $0.864(0.002)^{*}$ & $0.854(0.005)^{*}$ & $1.006(1.0 \mathrm{e}-05)^{*}$ \\
\hline$\alpha+\beta$ & 0.850 & 0.240 & 0.858 & 0.921 & 1.017 \\
\hline
\end{tabular}

Notes: Standard errors are in parentheses.* denotes rejection of the null hypothesis at $1 \%, 5 \%$ or $10 \%$ significance level. 
Table 5 - Estimation results of DCC-GARCH(1,1) models (sample period: 2003/03/122007/10/12)

\begin{tabular}{|c|c|c|c|c|c|}
\hline & Oil & Gas & Elec & Gold & Silver \\
\hline$\mu$ & $8.1 \mathrm{e}-04(5.5 \mathrm{e}-04)$ & $8.9 \mathrm{e}-04(1.4 \mathrm{e}-03)$ & $1.7 \mathrm{e}-03(2.3 \mathrm{e}-03)$ & $5.7 \mathrm{e}-04(2.3 \mathrm{e}-04)^{*}$ & 7.9e-04 (4.5e-04)* \\
\hline$\omega$ & $1.1 \mathrm{e}-05(3.5 \mathrm{e}-07)^{*}$ & $1.3 \mathrm{e}-04(6.7 \mathrm{e}-07)^{*}$ & $7.1 \mathrm{e}-04(8.9 \mathrm{e}-05)^{*}$ & $7.5 \mathrm{e}-07(7.7 \mathrm{e}-08)^{*}$ & $7.8 \mathrm{e}-06(7.3 \mathrm{e}-07)^{*}$ \\
\hline$\alpha$ & $0.029(5.2 \mathrm{e}-03)^{*}$ & $0.038(3.1 \mathrm{e}-03)^{*}$ & $0.313(0.009)^{*}$ & $0.024(9.7 \mathrm{e}-04)^{*}$ & $0.077(0.002)^{*}$ \\
\hline$\beta$ & $0.943(5.5 \mathrm{e}-03)^{*}$ & $0.898(0.003)^{*}$ & $0.637(0.003)^{*}$ & $0.968(8.7 \mathrm{e}-04)^{*}$ & $0.908(0.002)^{*}$ \\
\hline \multirow[t]{2}{*}{$\alpha+\beta$} & 0.972 & 0.936 & 0.950 & 0.992 & 0.985 \\
\hline & Platinum & Palladium & Cotton & Lumber & Aluminium \\
\hline$\mu$ & $7.9 \mathrm{e}-04(1.2 \mathrm{e}-04)^{*}$ & $1.4 \mathrm{e}-04(6.2 \mathrm{e}-04)$ & $1.9 \mathrm{e}-04(4.9 \mathrm{e}-04)$ & $-1.3 \mathrm{e}-04(4.9 \mathrm{e}-04)$ & 2.7e-04 (3.0e-04) \\
\hline$\omega$ & $6.8 \mathrm{e}-06(5.3 e-07)^{*}$ & $1.3 \mathrm{e}-05(4.5 \mathrm{e}-08)^{*}$ & $2.3 \mathrm{e}-06(2.2 \mathrm{e}-07)^{*}$ & $5.3 \mathrm{e}-06(3.8 \mathrm{e}-07)^{*}$ & $3.4 \mathrm{e}-06(2.5 \mathrm{e}-07)^{*}$ \\
\hline$\alpha$ & $0.149(0.005)^{*}$ & $0.108(2.4 \mathrm{e}-04)^{*}$ & $0.018(7.2 \mathrm{e}-04)^{*}$ & $0.014(1.2 \mathrm{e}-03)^{*}$ & $0.045(0.001)^{*}$ \\
\hline$\beta$ & $0.812(0.004)^{*}$ & $0.858(0.003)^{*}$ & $0.974(6.6 \mathrm{e}-04)^{*}$ & $0.968(1.1 \mathrm{e}-03)$ & $0.937(0.001)^{*}$ \\
\hline \multirow[t]{2}{*}{$\alpha+\beta$} & 0.961 & 0.966 & 0.992 & 0.982 & 0.982 \\
\hline & Copper & Zinc & Tin & Lead & Nickel \\
\hline$\mu$ & $0.001(4.1 \mathrm{e}-04)^{*}$ & $0.001(4.6 \mathrm{e}-04)^{*}$ & $7.8 \mathrm{e}-04(5.7 \mathrm{e}-04)$ & $0.002(7.5 \mathrm{e}-05)^{*}$ & $9.4 \mathrm{e}-04$ (5.9e-04) \\
\hline$\omega$ & $3.7 \mathrm{e}-06(3.7 \mathrm{e}-07)^{*}$ & $6.7 \mathrm{e}-06(6.5 \mathrm{e}-07)^{*}$ & $6.1 \mathrm{e}-05(2.5 \mathrm{e}-06)^{*}$ & $5.7 \mathrm{e}-05(2.4 \mathrm{e}-06)^{*}$ & $9.2 \mathrm{e}-06(9.6 \mathrm{e}-07)^{*}$ \\
\hline$\alpha$ & $0.051(0.001)^{*}$ & $0.066(0.002)^{*}$ & $0.086(0.007)^{*}$ & $0.109(0.008)^{*}$ & $0.048(0.001)^{*}$ \\
\hline$\beta$ & $0.936(0.001)^{*}$ & $0.917(0.002)^{*}$ & $0.752(0.007)^{*}$ & $0.763(0.006)^{*}$ & $0.938(0.001)^{*}$ \\
\hline \multirow[t]{2}{*}{$\alpha+\beta$} & 0.987 & 0.983 & 0.838 & 0.872 & 0.986 \\
\hline & Corn & Wheat & Palm oil & Soybean oil & Cocoa \\
\hline$\mu$ & $4.8 \mathrm{e}-04(4.9 \mathrm{e}-04)$ & $0.001(5.7 \mathrm{e}-04)^{*}$ & $5.1 \mathrm{e}-04(6.5 \mathrm{e}-04)$ & $8.5 \mathrm{e}-04(4.0 \mathrm{e}-04)^{*}$ & $-1.7 \mathrm{e}-04(8.4 \mathrm{e}-04)$ \\
\hline$\omega$ & $3.5 \mathrm{e}-06(2.8 \mathrm{e}-07)^{*}$ & $4.9 \mathrm{e}-06(2.8 \mathrm{e}-07)^{*}$ & $4.9 \mathrm{e}-05(1.8 \mathrm{e}-06)^{*}$ & $5.1 \mathrm{e}-07(2.8 \mathrm{e}-08)^{*}$ & $1.2 \mathrm{e}-04(5.1 \mathrm{e}-06)^{*}$ \\
\hline$\alpha$ & $0.019(5.1 \mathrm{e}-04)$ & $0.005(7.4 \mathrm{e}-04)^{*}$ & $0.051(0.005)^{*}$ & $0.014(5.0 \mathrm{e}-04)^{*}$ & $0.015(9.8 \mathrm{e}-03)$ \\
\hline$\beta$ & $0.969(8.9 \mathrm{e}-04)^{*}$ & $0.982(6.6 \mathrm{e}-04)^{*}$ & $0.837(0.005)^{*}$ & $0.983(4.3 \mathrm{e}-04)^{*}$ & $0.776(8.8 \mathrm{e}-03)^{*}$ \\
\hline \multirow[t]{2}{*}{$\alpha+\beta$} & 0.988 & 0.987 & 0.888 & 0.997 & 0.791 \\
\hline & Coffee & Sugar & Lean & Feeder & Live \\
\hline$\mu$ & $6.5 \mathrm{e}-04(5.5 \mathrm{e}-04)$ & $1.2 \mathrm{e}-04(6.2 \mathrm{e}-04)$ & $2.5 e-04(9.3 e-04)$ & $2.9 \mathrm{e}-04(4.8 \mathrm{e}-04)$ & $2.2 \mathrm{e}-04(4.4 \mathrm{e}-04)$ \\
\hline$\omega$ & $1.4 \mathrm{e}-06(5.8 \mathrm{e}-06)$ & $6.3 \mathrm{e}-05(2.7 \mathrm{e}-06)^{*}$ & $9.2 \mathrm{e}-04(2.1 \mathrm{e}-05)^{*}$ & $4.5 \mathrm{e}-05(2.0 \mathrm{e}-06)^{*}$ & $4.8 \mathrm{e}-05(1.9 \mathrm{e}-06)^{*}$ \\
\hline$\alpha$ & $0.012(4.3 \mathrm{e}-04)^{*}$ & $0.040(0.004)^{*}$ & $0.013(0.023)$ & $0.050(0.009)^{*}$ & $0.044(0.008)^{*}$ \\
\hline$\beta$ & $0.984(4.1 \mathrm{e}-04)^{*}$ & $0.811(0.006)^{*}$ & $0.545(0.035)^{*}$ & $0.699(0.011)^{*}$ & $0.682(0.011)^{*}$ \\
\hline$\alpha+\beta$ & 0.993 & 0.851 & 0.658 & 0.749 & 0.726 \\
\hline
\end{tabular}

Notes: Standard errors are in parentheses.* denotes rejection of the null hypothesis at $1 \%, 5 \%$ or $10 \%$ significance level. 
Table 6 - Estimation results of DCC-GARCH(1,1) models (sample period: 2007/10/132009/03/06)

\begin{tabular}{|c|c|c|c|c|c|}
\hline & Oil & Gas & Elec & Gold & Silver \\
\hline$\mu$ & $9.6 \mathrm{e}-04(1.3 \mathrm{e}-03)$ & $-1.1 \mathrm{e}-03(1.7 \mathrm{e}-03)$ & $3.7 e-04(3.8 \mathrm{e}-03)$ & 7.2e-04 (8.6e-04) & $1.5 \mathrm{e}-03(1.2 \mathrm{e}-03)$ \\
\hline$\omega$ & $1.6 \mathrm{e}-05(5.3 \mathrm{e}-06)^{*}$ & $2.1 \mathrm{e}-03(1.2 \mathrm{e}-04)^{*}$ & $5.0 \mathrm{e}-04(1.1 \mathrm{e}-04)^{*}$ & $7.1 \mathrm{e}-06(8.9 \mathrm{e}-07)^{*}$ & $3.8 \mathrm{e}-05(4.2 \mathrm{e}-06)^{*}$ \\
\hline$\alpha$ & $0.120(9.3 \mathrm{e}-03)^{*}$ & $0.021(0.014)^{*}$ & $0.240(0.018)^{*}$ & $0.030(3.1 \mathrm{e}-03)^{*}$ & $0.074(4.8 \mathrm{e}-03)^{*}$ \\
\hline$\beta$ & $0.878(8.3 \mathrm{e}-03)^{*}$ & $0.902(0.063)^{*}$ & $0.713(0.010)^{*}$ & $0.948(2.9 \mathrm{e}-03)^{*}$ & $0.888(4.3 \mathrm{e}-03)^{*}$ \\
\hline \multirow[t]{2}{*}{$\alpha+\beta$} & 0.998 & 0.923 & 0.953 & 0.978 & 0.962 \\
\hline & Platinum & Palladium & Cotton & Lumber & Aluminium \\
\hline$\mu$ & $-5.7 e-04(8.0 e-04)$ & $-2.2 \mathrm{e}-03(1.9 \mathrm{e}-03)$ & $5.5 \mathrm{e}-04(1.1 \mathrm{e}-03)$ & $2.2 \mathrm{e}-03(1.7 \mathrm{e}-03)$ & $-1.0 \mathrm{e}-03(1.3 \mathrm{e}-03)$ \\
\hline$\omega$ & $5.2 \mathrm{e}-04(4.4 \mathrm{e}-05)^{*}$ & $1.0 \mathrm{e}-03(6.3 \mathrm{e}-08)^{*}$ & $9.1 \mathrm{e}-05(8.7 \mathrm{e}-06)^{*}$ & $5.1 \mathrm{e}-04(2.7 \mathrm{e}-05)^{*}$ & $8.7 \mathrm{e}-06(6.9 \mathrm{e}-08)^{*}$ \\
\hline$\alpha$ & $0.168(0.099)^{*}$ & $0.013(0.029)$ & $0.142(0.023)^{*}$ & $0.011(0.030)$ & $0.076(0.023)^{*}$ \\
\hline$\beta$ & $0.115(0.096)$ & $0.300(0.041)^{*}$ & $0.713(0.017)^{*}$ & $0.375(0.033)^{*}$ & $0.902(0.015)^{*}$ \\
\hline \multirow[t]{2}{*}{$\alpha+\beta$} & 0.283 & 0.336 & 0.855 & 0.386 & 0.978 \\
\hline & Copper & Zinc & Tin & Lead & Nickel \\
\hline$\mu$ & $-6.3(8.9 \mathrm{e}-04)$ & $-1.8 \mathrm{e}-03(1.2 \mathrm{e}-03)$ & $7.6 \mathrm{e}-04(1.1 \mathrm{e}-03)$ & $-2.6 e-03(7.1 e-03)$ & $-2.8 \mathrm{e}-03(1.5 \mathrm{e}-03)^{*}$ \\
\hline$\omega$ & $9.0 \mathrm{e}-06(5.0 \mathrm{e}-09)^{*}$ & $5.8 \mathrm{e}-05(5.1 \mathrm{e}-06)^{*}$ & $2.0 \mathrm{e}-05(2.1 \mathrm{e}-06)^{*}$ & $1.6 \mathrm{e}-05(1.0 \mathrm{e}-06)^{*}$ & $7.2 \mathrm{e}-05(4.9 \mathrm{e}-08)^{*}$ \\
\hline$\alpha$ & $0.110(0.010)^{*}$ & $0.045(6.0 \mathrm{e}-03)^{*}$ & $0.089(5.1 \mathrm{e}-03)^{*}$ & $0.036(8.7 \mathrm{e}-03)^{*}$ & $0.130(0.013)^{*}$ \\
\hline$\beta$ & $0.883(8.4 \mathrm{e}-03)^{*}$ & $0.893(5.6 \mathrm{e}-03)^{*}$ & $0.885(4.3 \mathrm{e}-03)^{*}$ & $0.951(3.4 \mathrm{e}-03)^{*}$ & $0.810(9.8 \mathrm{e}-03)^{*}$ \\
\hline \multirow[t]{2}{*}{$\alpha+\beta$} & 0.993 & 0.938 & 0.974 & 0.987 & 0.940 \\
\hline & Corn & Wheat & Palm oil & Soybean oil & Cocoa \\
\hline$\mu$ & $2.1 \mathrm{e}-03(1.7 \mathrm{e}-03)^{*}$ & $-1.1(1.3 \mathrm{e}-03)$ & $1.2 \mathrm{e}-03(1.2 \mathrm{e}-03)$ & $1.7 \mathrm{e}-03(9.9 \mathrm{e}-04)$ & $1.8 \mathrm{e}-03(1.0 \mathrm{e}-03)^{*}$ \\
\hline$\omega$ & $1.0 \mathrm{e}-05(2.1 \mathrm{e}-06)^{*}$ & $1.0 \mathrm{e}-04(1.3 \mathrm{e}-05)^{*}$ & $3.0 \mathrm{e}-05(1.9 \mathrm{e}-06)^{*}$ & $9.5 \mathrm{e}-06(1.9 \mathrm{e}-06)^{*}$ & $5.0 \mathrm{e}-06(1.1 \mathrm{e}-06)^{*}$ \\
\hline$\alpha$ & $0.069(6.4 \mathrm{e}-03)^{*}$ & $0.137(0.019)^{*}$ & $0.069(4.4 \mathrm{e}-03)^{*}$ & $0.093(8.1 \mathrm{e}-03)^{*}$ & $0.061(3.4 \mathrm{e}-03)^{*}$ \\
\hline$\beta$ & $0.915(5.3 \mathrm{e}-03)^{*}$ & $0.741(0.017)^{*}$ & $0.898(6.4 \mathrm{e}-03)^{*}$ & $0.894(6.4 \mathrm{e}-03)^{*}$ & $0.938(2.6 \mathrm{e}-03)^{*}$ \\
\hline \multirow[t]{2}{*}{$\alpha+\beta$} & 0.984 & 0.878 & 0.967 & 0.987 & 0.999 \\
\hline & Coffee & Sugar & Lean & Feeder & Live \\
\hline$\mu$ & $2.9 \mathrm{e}-04(8.5 \mathrm{e}-04)$ & $1.4 \mathrm{e}-03(1.1 \mathrm{e}-03)$ & $1.7 \mathrm{e}-03(1.4 \mathrm{e}-03)$ & $-4.2 \mathrm{e}-04(3.4 \mathrm{e}-04)$ & $-1.2 \mathrm{e}-04(5.2 \mathrm{e}-04)$ \\
\hline$\omega$ & $2.2 \mathrm{e}-04(1.4 \mathrm{e}-05)^{*}$ & $1.1 \mathrm{e}-05(3.0 \mathrm{e}-06)^{*}$ & $3.6 \mathrm{e}-04(7.0 \mathrm{e}-05)^{*}$ & $1.5 \mathrm{e}-05(7.1 \mathrm{e}-07)^{*}$ & $5.9 \mathrm{e}-06(1.6 \mathrm{e}-07)^{*}$ \\
\hline$\alpha$ & $0.161(0.027)^{*}$ & $0.119(9.8 \mathrm{e}-03)^{*}$ & $0.029(6.8 \mathrm{e}-04)^{*}$ & $-7.4 \mathrm{e}-03(3.6 \mathrm{e}-03)^{*}$ & $0.015(8.8 \mathrm{e}-04)^{*}$ \\
\hline$\beta$ & $0.268(0.013)^{*}$ & $0.880(5.6 \mathrm{e}-03)^{*}$ & $0.383(0.011)^{*}$ & $0.855(6.4 \mathrm{e}-03)^{*}$ & $0.980(6.5 \mathrm{e}-04)^{*}$ \\
\hline$\alpha+\beta$ & 0.429 & 0.999 & 0.412 & 0.892 & 0.995 \\
\hline
\end{tabular}

Notes: Standard errors are in parentheses.* denotes rejection of the null hypothesis at $1 \%, 5 \%$ or $10 \%$ significance level. 
Table 7 - Estimation results of DCC-GARCH(1,1) models (sample period: 2009/03/072011/11/28)

\begin{tabular}{|c|c|c|c|c|c|}
\hline & Oil & Gas & Elec & Gold & Silver \\
\hline$\mu$ & $1.2 \mathrm{e}-03(7.3 \mathrm{e}-04)$ & $-1.5 e-03(1.1 \mathrm{e}-03)$ & $1.3 e-03(3.6 e-03)$ & 9.0e-04 (3.1e-04) & $0.001(8.4 \mathrm{e}-04)^{*}$ \\
\hline$\omega$ & $2.1 \mathrm{e}-04(1.0 \mathrm{e}-05)^{*}$ & $1.6 \mathrm{e}-05(1.1 \mathrm{e}-05)$ & $1.0 \mathrm{e}-03(2.9 \mathrm{e}-04)^{*}$ & $3.5 \mathrm{e}-06(1.2 \mathrm{e}-09)^{*}$ & $1.0 \mathrm{e}-04(7.8 \mathrm{e}-06)^{*}$ \\
\hline$\alpha$ & $0.071(0.015)^{*}$ & $0.101(0.030)^{*}$ & $0.427(0.127)^{*}$ & $0.065(0.003)^{*}$ & $0.162(0.012)^{*}$ \\
\hline$\beta$ & $0.575(0.017)^{*}$ & $0.891(0.023)^{*}$ & $0.518(0.065)^{*}$ & $0.907(0.003)^{*}$ & $0.690(0.012)^{*}$ \\
\hline \multirow[t]{2}{*}{$\alpha+\beta$} & 0.646 & 0.992 & 0.945 & 0.972 & 0.852 \\
\hline & Platinum & Palladium & Cotton & Lumber & Aluminium \\
\hline$\mu$ & $1.0 \mathrm{e}-04(8.0 \mathrm{e}-04)$ & $6.3 e-04(1.1 e-04)$ & $1.7 \mathrm{e}-04(7.5 \mathrm{e}-04)^{*}$ & $3.6 \mathrm{e}-04(8.8 \mathrm{e}-04)$ & $6.8 \mathrm{e}-04(5.5 \mathrm{e}-04)$ \\
\hline$\omega$ & $2.0 \mathrm{e}-04(1.2 \mathrm{e}-05)^{*}$ & $4.5 \mathrm{e}-04(2.8 \mathrm{e}-06)^{*}$ & $1.5 \mathrm{e}-06(3.4 \mathrm{e}-06)^{*}$ & 5.0e-04 (1.6e-05)* & $6.1 \mathrm{e}-06(8.5 \mathrm{e}-07)^{*}$ \\
\hline$\alpha$ & $0.074(0.039)^{*}$ & $0.119(0.035)^{*}$ & $0.048(0.007)^{*}$ & $0.067(0.028)^{*}$ & $0.024(0.001)^{*}$ \\
\hline$\beta$ & $0.315(0.039)^{*}$ & $0.264(0.036)^{*}$ & $0.951(0.008)^{*}$ & $0.192(0.010)^{*}$ & $0.951(0.001)^{*}$ \\
\hline \multirow[t]{2}{*}{$\alpha+\beta$} & 0.389 & 0.383 & 0.999 & 0.259 & 0.975 \\
\hline & Copper & Zinc & Tin & Lead & Nickel \\
\hline$\mu$ & $0.001(5.9 \mathrm{e}-04)^{*}$ & $1.1 \mathrm{e}-03(7.7 \mathrm{e}-04)$ & $1.1 \mathrm{e}-03(6.7 \mathrm{e}-04)^{*}$ & $0.001(8.4 \mathrm{e}-04)$ & $1.0 \mathrm{e}-03(6.1 \mathrm{e}-04)^{*}$ \\
\hline$\omega$ & $1.2 \mathrm{e}-06(1.3 \mathrm{e}-06)^{*}$ & $1.9 \mathrm{e}-05(1.5 \mathrm{e}-06)^{*}$ & $9.1 \mathrm{e}-05(1.0 \mathrm{e}-04)^{*}$ & $2.0 \mathrm{e}-05(1.9 \mathrm{e}-06)^{*}$ & $8.9 \mathrm{e}-06(5.8 \mathrm{e}-07)^{*}$ \\
\hline$\alpha$ & $0.078(0.004)^{*}$ & $0.046(0.022)^{*}$ & $0.114(0.080)^{*}$ & $0.044(0.003)^{*}$ & $0.126(0.015)^{*}$ \\
\hline$\beta$ & $0.887(0.004)^{*}$ & $0.917(0.044)^{*}$ & $0.666(0.306)^{*}$ & $0.922(0.003)^{*}$ & $0.428(0.022)^{*}$ \\
\hline \multirow[t]{2}{*}{$\alpha+\beta$} & 0.965 & 0.963 & 0.780 & 0.966 & 0.554 \\
\hline & Corn & Wheat & Palm oil & Soybean oil & Cocoa \\
\hline$\mu$ & $9.0 \mathrm{e}-04(7.4 \mathrm{e}-04)$ & $2.5 \mathrm{e}-04(1.1 \mathrm{e}-03)$ & $6.8 \mathrm{e}-04(6.1 \mathrm{e}-04)$ & $9.4 \mathrm{e}-04(4.2 \mathrm{e}-04)^{*}$ & $9.4 \mathrm{e}-05(6.5 \mathrm{e}-04)$ \\
\hline$\omega$ & $3.2 \mathrm{e}-04(1.3 \mathrm{e}-04)^{*}$ & $9.8 \mathrm{e}-05(2.3 \mathrm{e}-06)^{*}$ & $2.6 \mathrm{e}-06(1.9 \mathrm{e}-07)^{*}$ & $8.4 \mathrm{e}-06(6.6 \mathrm{e}-07)^{*}$ & $1.0 \mathrm{e}-04(5.0 \mathrm{e}-06)^{*}$ \\
\hline$\alpha$ & $0.097(0.028)^{*}$ & $0.013(0.007)^{*}$ & $0.020(7.7 \mathrm{e}-04)^{*}$ & $0.043(0.003)^{*}$ & $0.070(0.012)^{*}$ \\
\hline$\beta$ & $0.183(0.029)^{*}$ & $0.857(0.006)^{*}$ & $0.969(6.5 \mathrm{e}-04)^{*}$ & $0.908(0.003)^{*}$ & $0.630(0.014)^{*}$ \\
\hline \multirow[t]{2}{*}{$\alpha+\beta$} & 0.280 & 0.870 & 0.989 & 0.951 & 0.700 \\
\hline & Coffee & Sugar & Lean & Feeder & Live \\
\hline$\mu$ & $9.3 e-04(5.6 e-04)$ & $0.001(9.5 \mathrm{e}-04)$ & 7.2e-04 (6.9e-04) & $8.2 \mathrm{e}-04(2.9 \mathrm{e}-04)^{*}$ & $7.8 \mathrm{e}-04(4.2 \mathrm{e}-04)^{*}$ \\
\hline$\omega$ & $8.7 \mathrm{e}-06(5.5 \mathrm{e}-07)^{*}$ & $1.5 \mathrm{e}-04(8.5 \mathrm{e}-06)^{*}$ & $2.4 \mathrm{e}-04(4.4 \mathrm{e}-06)^{*}$ & $6.6 \mathrm{e}-05(2.4 \mathrm{e}-06)^{*}$ & $1.1 \mathrm{e}-05(3.7 \mathrm{e}-07)^{*}$ \\
\hline$\alpha$ & $0.016(0.001)^{*}$ & $0.085(0.012)^{*}$ & $0.044(0.011)^{*}$ & $0.068(0.027)^{*}$ & $0.026(1.9 \mathrm{e}-03)^{*}$ \\
\hline$\beta$ & $0.952(0.001)^{*}$ & $0.705(0.011)^{*}$ & $0.334(0.010)^{*}$ & $0.027(0.035)^{*}$ & $0.920(2.7 \mathrm{e}-03)^{*}$ \\
\hline$\alpha+\beta$ & 0.968 & 0.790 & 0.378 & 0.095 & 0.920 \\
\hline
\end{tabular}

Notes: Standard errors are in parentheses.* denotes rejection of the null hypothesis at $1 \%, 5 \%$ or $10 \%$ significance level. 


\section{Appendix}

Figures A1. Dynamic conditional correlations

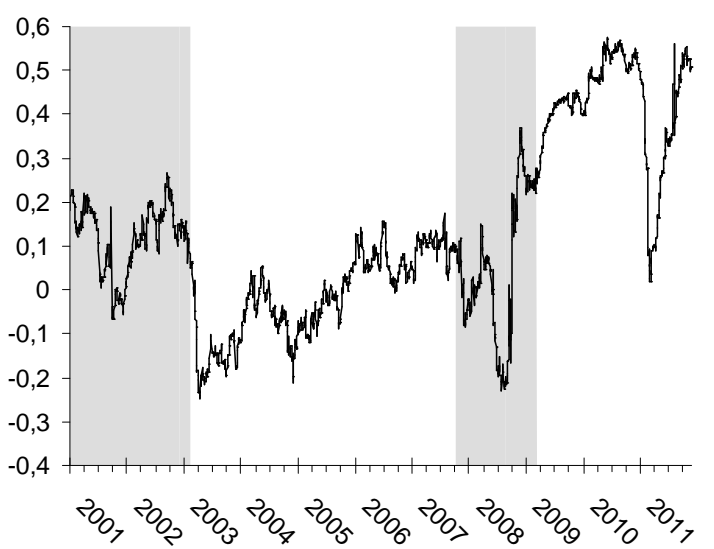

Oil / S\&P 500

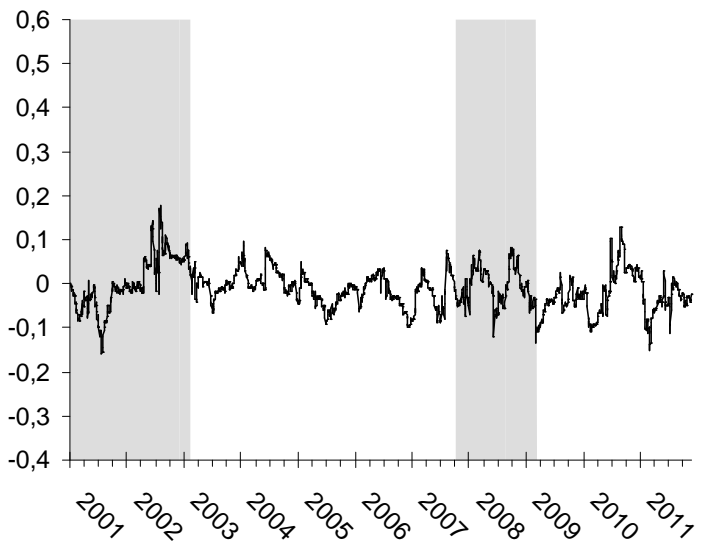

Electricity / S\&P 500

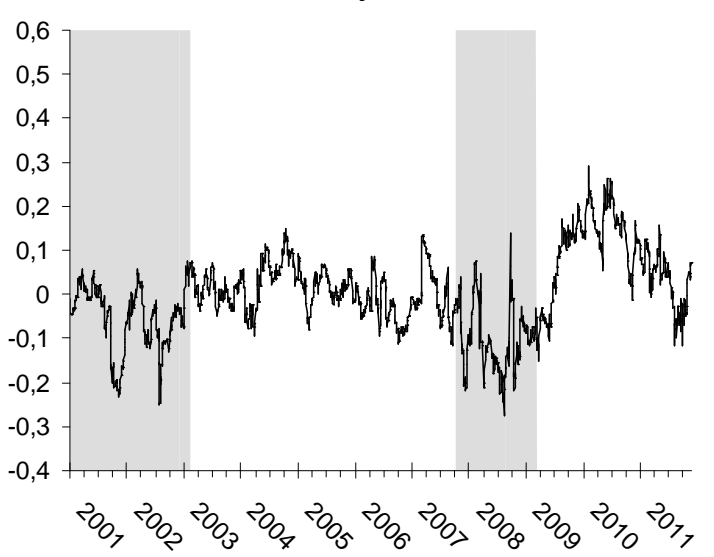

Silver / S\&P 500

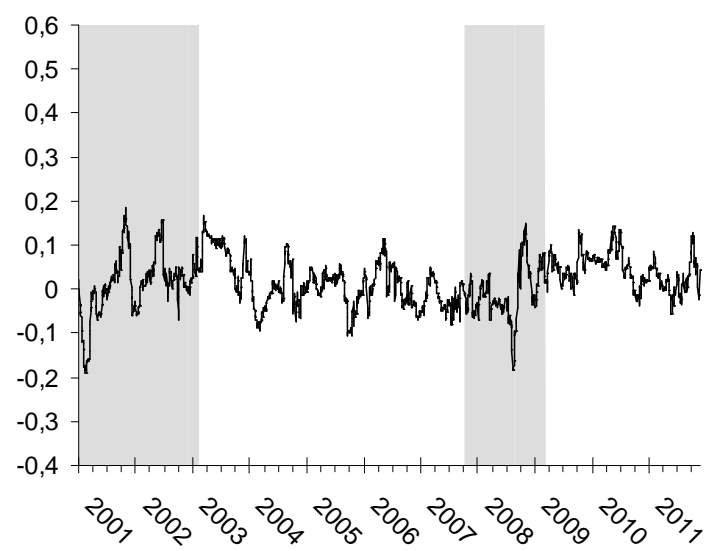

Gas / S\&P 500

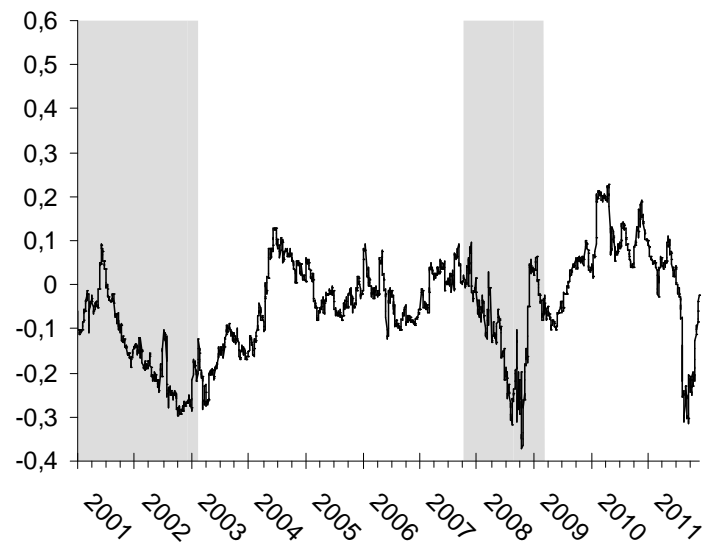

Gold / S\&P 500

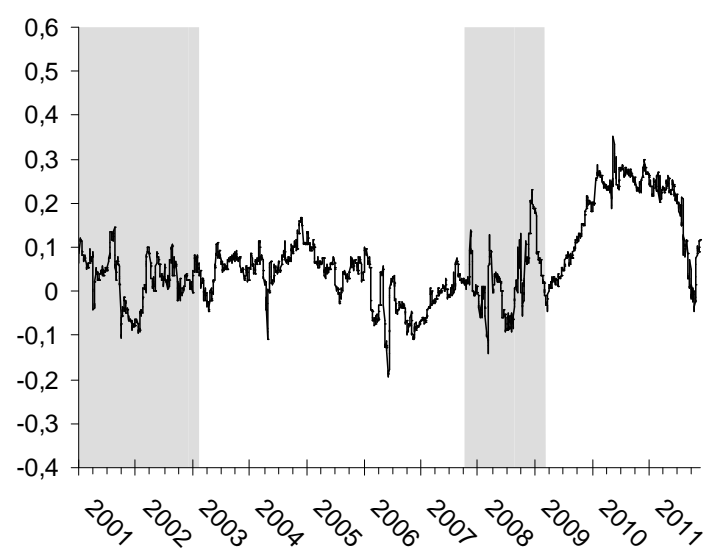

Platinum / S\&P 500 


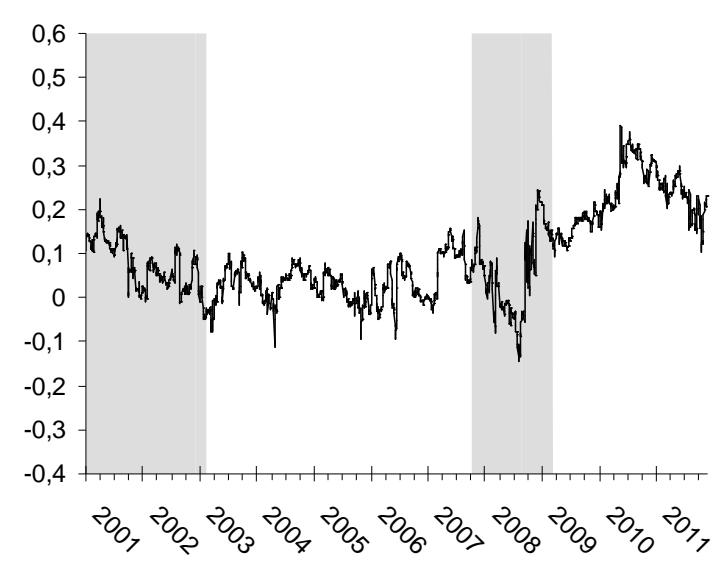

Palladium / S\&P 500

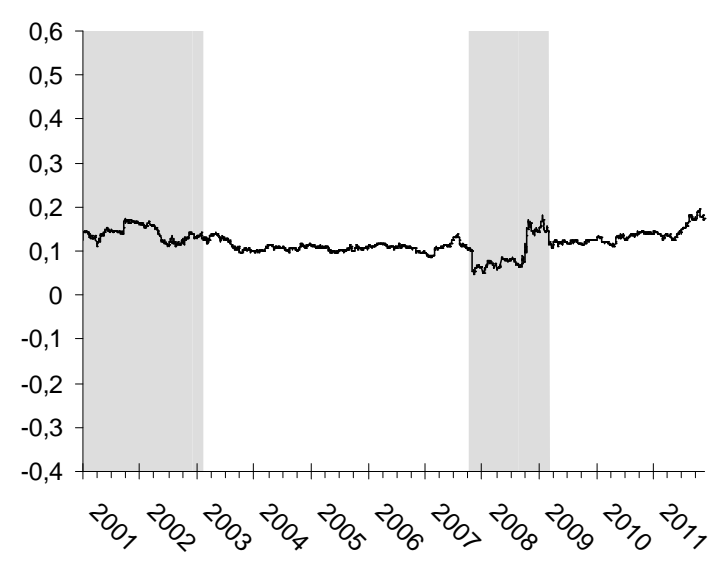

Lumber / S\&P 500

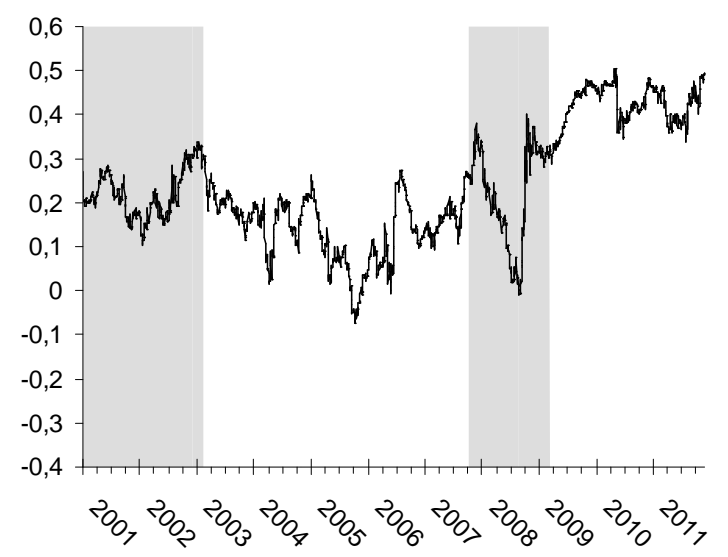

Copper / S\&P 500

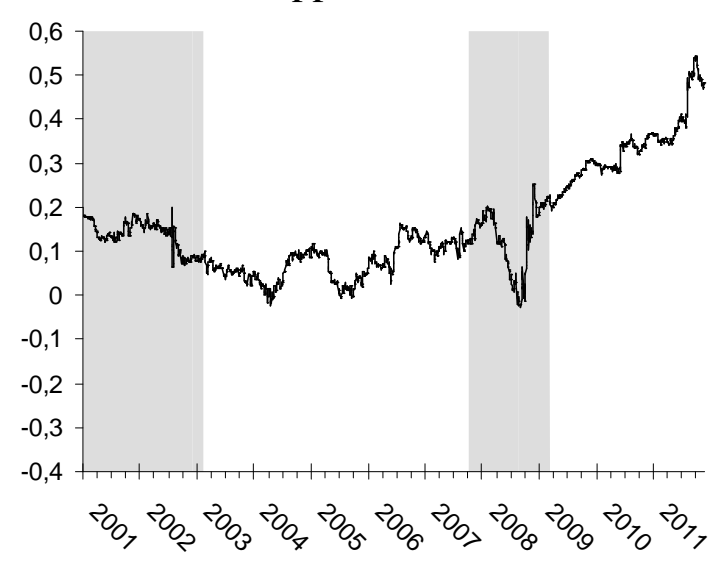

Tin / S\&P 500

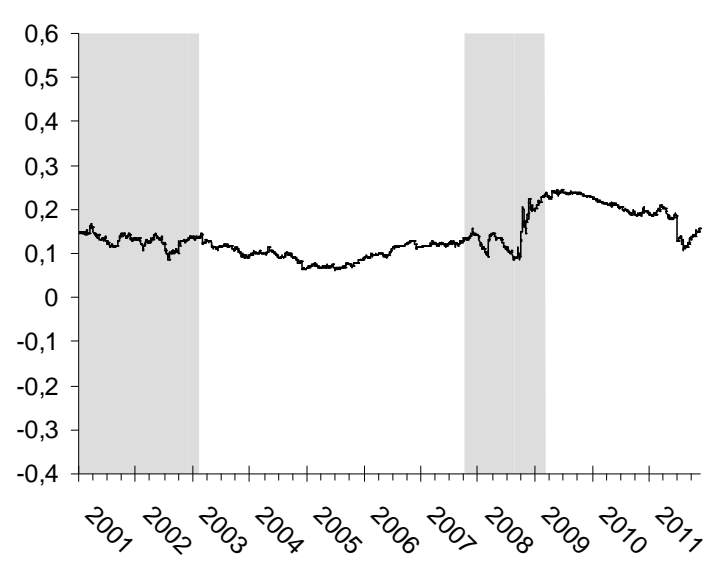

Cotton / S\&P 500

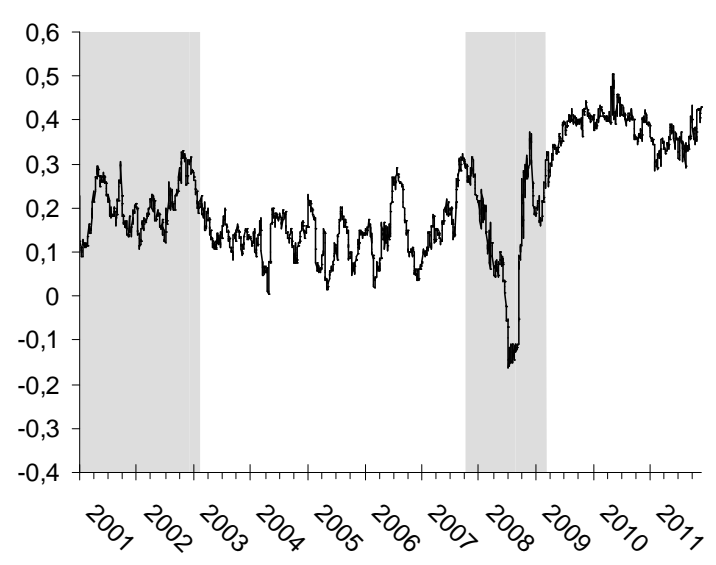

Aluminium / S\&P 500

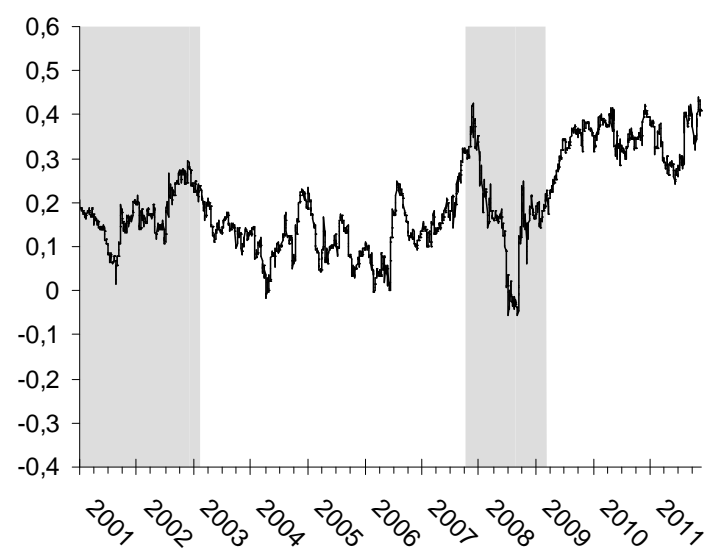

Zinc / S\&P 500

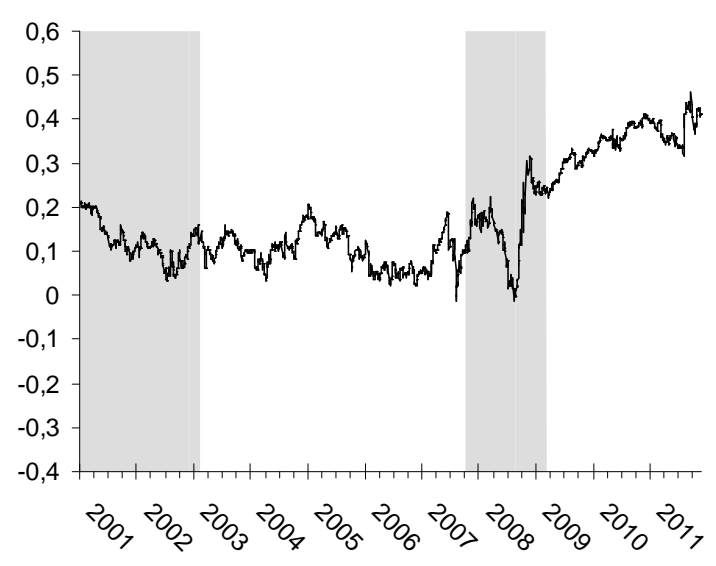

Lead / S\&P 500 


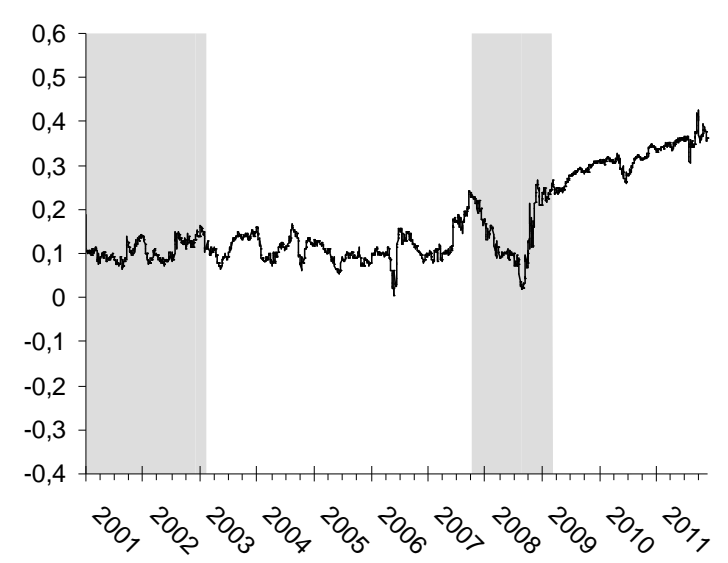

Nickel / S\&P 500

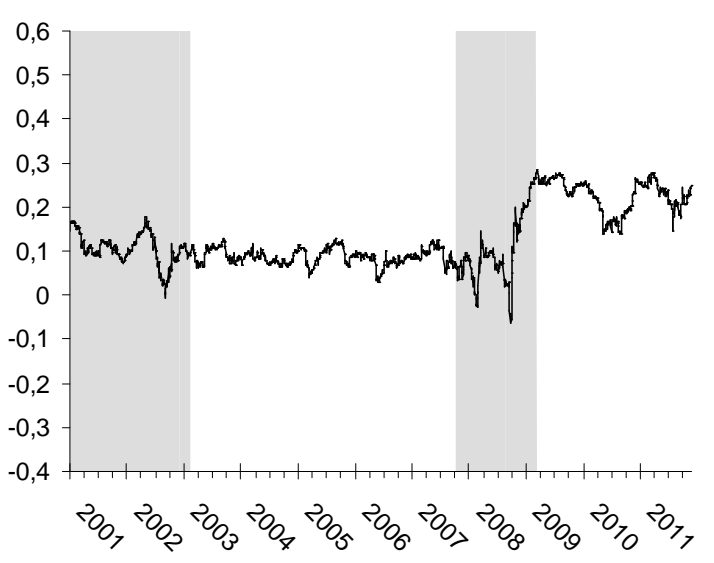

Wheat / S\&P 500

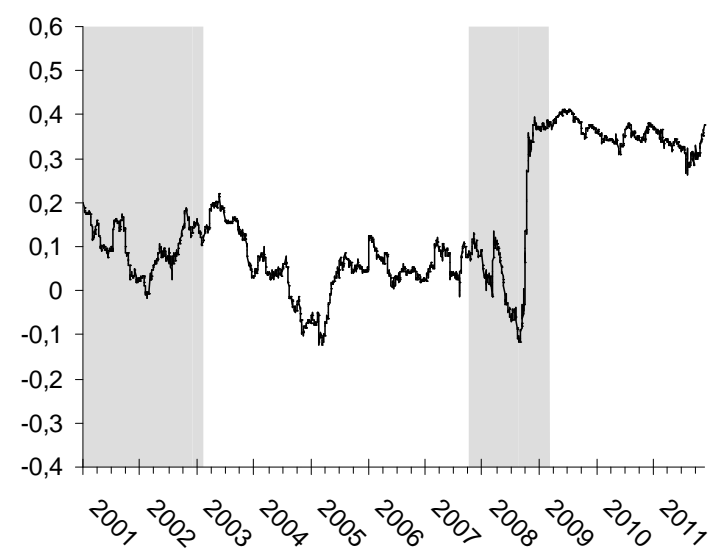

Soybean oil / S\&P 500

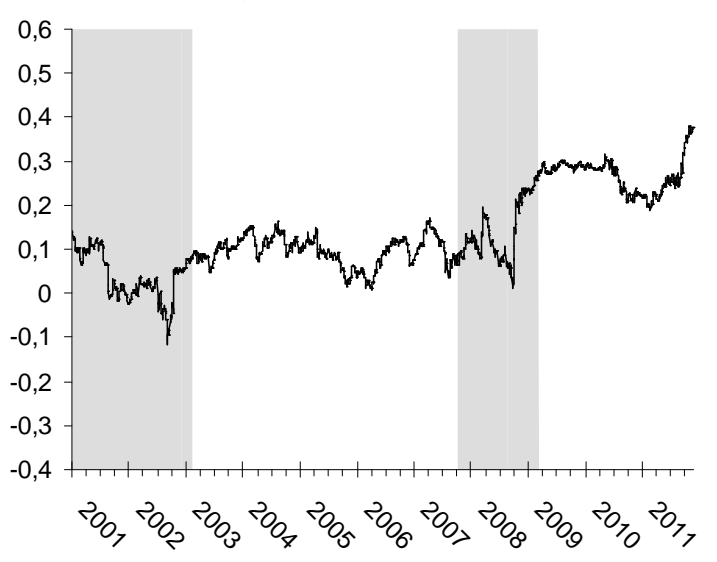

Coffee / S\&P 500

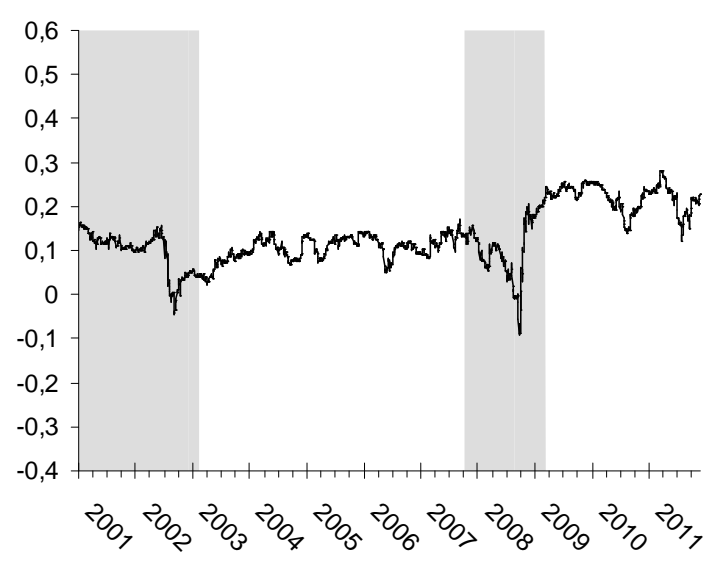

Corn / S\&P 500

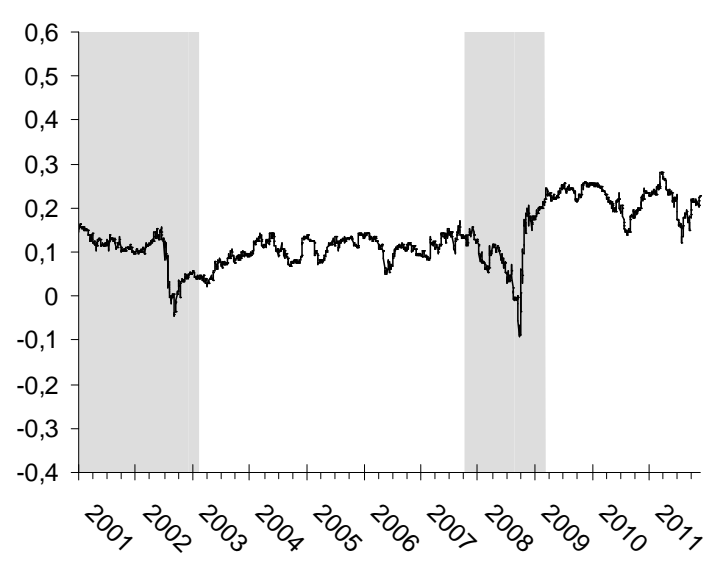

Palm oil / S\&P 500

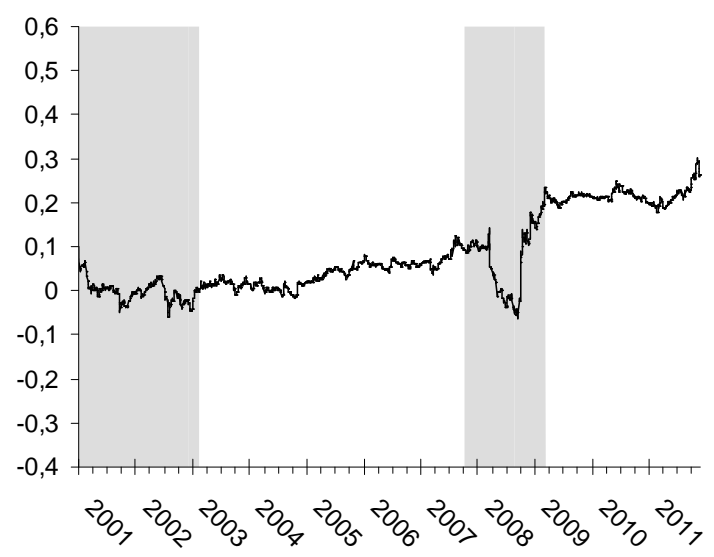

Cocoa / S\&P 500

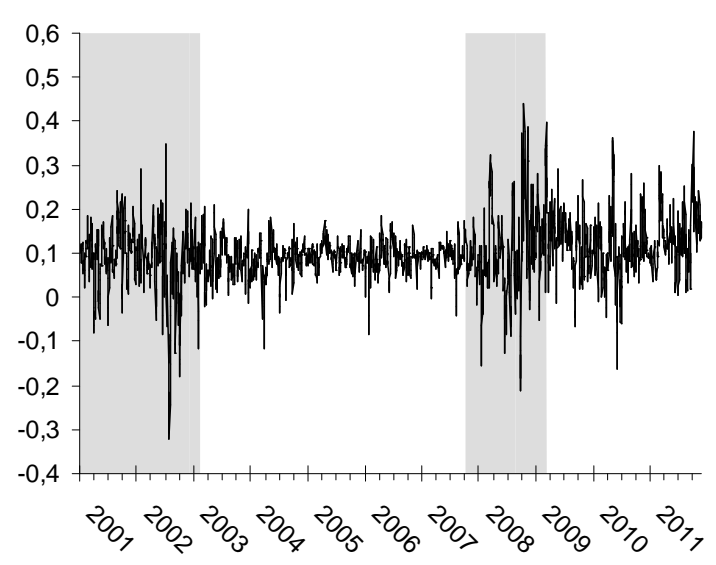

Sugar / S\&P 500 


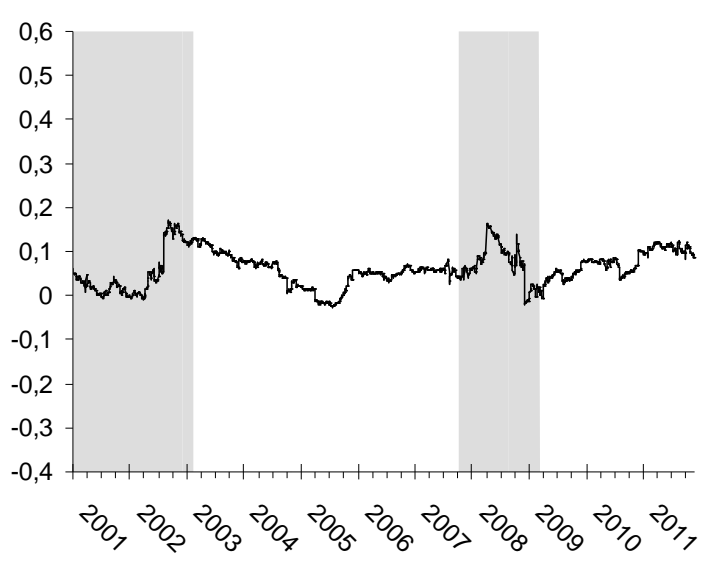

Lean / S\&P 500

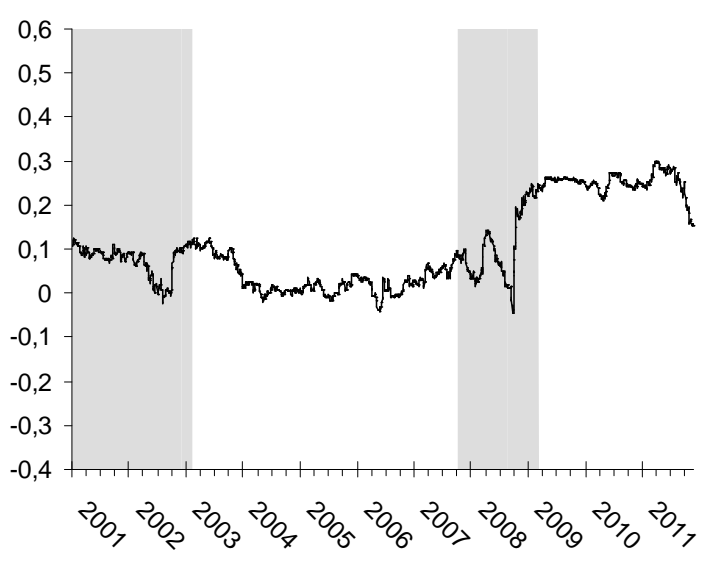

Live / S\&P 500

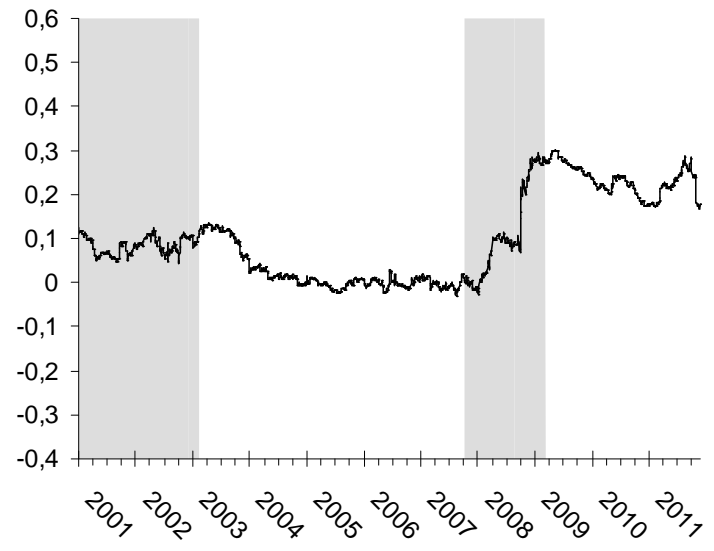

Feeder / S\&P 500

Note: The grey bands correspond to periods of bearish stock market, the white stripes corresponding to periods of bullish stock market. These periods have been identified on the basis of the evolution of S\&P 500 stock returns using the Bai and Perron (2003) structural break test. 


\section{LIST OF WORKING PAPERS RELEASED BY CEPII}

An Exhaustive list is available on the website: ॥www.cepii.fr.

No

Title

Authors

2012-19 European Export Performance

L. Fontagné, A. Cheptea

\& S. Zignago

2012-18 The Few Leading the Many: Foreign Affiliates and Business Cycle Comovement

J. Kleinert, J. Martin \& F. Toubal

2012-17 Native Language, Spoken Language, Translation and Trade

2012-16 Assessing the Price-Raising Effect of Non-Tariff Measures in Africa

O.Cadot \& J.Gourdon

2012-15 International Migration and Trade Agreements: the New Role of PTAs

2012-14 Scanning the Ups and Downs of China's Trade Imbalances

J. Melitz \& F. Toubal

2012-13 Revisiting the Theory of Optimum Currency Areas: Is the CFA Franc Zone Sustainable?

C. Couharde,

I. Coulibaly, D. Guerreiro \& V. Mignon

2012-12 Macroeconomic Transmission of Eurozone Shocks to B. Erten Emerging Economies

2012-11 The fiscal Impact of Immigration in France: a Generational Accounting Approach

X. Chojnicki

2012-10 MAcMap-HS6 2007, an Exhaustive and Consistent Measure of Applied Protection in 2007

H. Guimbard, S. Jean, M. Mimouni \& X. Pichot 
2012-09 Regional Integration and Natural Resources: Who Benefits? Evidence from MENA

2012-08 A Foreign Direct Investment Database for Global CGE Models

2012-07

On Currency Misalignments within the Euro Area

2012-06 How Frequently Firms Export? Evidence from France

2012-05 Fiscal Sustainability in the Presence of Systemic Banks: the Case of EU Countries

2012-04 Low-Wage Countries' Competition, Reallocation across Firms and the Quality Content of Exports

2012-03 The Great Shift: Macroeconomic Projections for the World Economy at the 2050 Horizon

2012-02 The Discriminatory E_ect of Domestic Regulations on International Services Trade: Evidence from FirmLevel Data

2012-01 Optimal food price stabilization in a small open developing country

2011-33 Export Dynamics and Sales at Home

2011-32 Entry on Difficult Export Markets by Chinese Domestic Firms: The Role of Foreign Export Spillovers

2011-31 French Firms at the Conquest of Asian Markets: The Role of Export Spillovers

2011-30 Environmental Policy and Trade Performance: Evidence from China
C. Carrère, J. Gourdon \& M. Olarreaga

C. Gouël, H. Guimbard \& D. Laborde

V. Coudert, C. Couharde \& V. Mignon

G. Békés, L. Fontagné, B. Muraközy \& V. Vicard

A. Bénassy-Quéré \& G. Roussellet

J. Martin \& I. Méjean

J. Fouré, A. Bénassy-Quéré \& L. Fontagné

M. Crozet, E. Milet \& D. Mirza

C. Gouël \& S. Jean

N. Berman, A. Berthou \& J. Héricourt

F. Mayneris \& S. Poncet

F. Mayneris \& S. Poncet L. Hering \& S. Poncet 
2011-29 Immigration, Unemployment and GDP in the Host Country: Bootstrap Panel Granger Causality Analysis on OECD Countries

2011-28 Index Trading and Agricultural Commodity Prices: A Panel Granger Causality Analysis

G. Capelle-Blancard \& D. Coulibaly

2011-27 The Impossible Trinity Revised: An Application to China

B. Carton

2011-26 Isolating the Network Effect of Immigrants on Trade

M. Aleksynska \& G. Peri

2011-25 Notes on CEPII's Distances Measures: The GeoDist Database

2011-24 Estimations of Tariff Equivalents for the Services Sectors

L. Fontagné, A. Guillin \& C. Mitaritonna

2011-23 Economic Impact of Potential Outcome of the DDA

Y. Decreux \& L. Fontagné

2011-22 More Bankers, more Growth? Evidence from OECD Countries

G. Capelle-Blancard \& C. Labonne

2011-21 EMU, EU, Market Integration and Consumption Smoothing

2011-20 Real Time Data and Fiscal Policy Analysis

J. Cimadomo

2011-19 On the inclusion of the Chinese renminbi in the SDR basket

A. Bénassy-Quéré \& D. Capelle

2011-18 Unilateral trade reform, Market Access and Foreign Competition: the Patterns of Multi-Product Exporters

M. Bas \& P. Bombarda

2011-17 The “Forward Premium Puzzle” and the Sovereign Default Risk

2011-16 Occupation-Education Mismatch of Immigrant Workers in Europe: Context and Policies

M. Aleksynska \& A. Tritah 
2011-15 Does Importing More Inputs Raise Exports? Firm Level Evidence from France

2011-14 Joint Estimates of Automatic and Discretionary Fiscal Policy: the OECD 1981-2003

2011-13 Immigration, vieillissement démographique et financement de la protection sociale : une évaluation par l'équilibre général calculable appliqué à la France

2011-12 The Performance of Socially Responsible Funds: Does the Screening Process Matter?

2011-11 Market Size, Competition, and the Product Mix of Exporters

2011-10 The Trade Unit Values Database

2011-09 Carbon Price Drivers: Phase I versus Phase II Equilibrium

2011-08 Rebalancing Growth in China: An International Perspective

2011-07 Economic Integration in the EuroMed: Current Status and Review of Studies

2011-06 The Decision to Import Capital Goods in India: Firms' Financial Factors Matter

2011-05 FDI from the South: the Role of Institutional Distance and Natural Resources

2011-04b What International Monetary System for a fastchanging World Economy?

2011-04a Quel système monétaire international pour une économie mondiale en mutation rapide?
M. Bas

\& V. Strauss-Kahn

J. Darby \& J. Mélitz

X. Chojnicki \& L. Ragot

G. Capelle-Blancard \& S. Monjon

T. Mayer, M. Melitz \& G. Ottaviano

A. Berthou \& C. Emlinger

A. Creti, P.-A. Jouvet \& V. Mignon

A. Bénassy-Quéré, B. Carton \& L. Gauvin

J. Jarreau

A. Berthou \& M. Bas

M. Aleksynska \& O. Havrylchyk

A. Bénassy-Quéré \& J. Pisani-Ferry

A. Bénassy-Quéré \& J. Pisani-Ferry 
No

Title

Authors

2011-03 China's Foreign Trade in the Perspective of a more Balanced Economic Growth

G. Gaulier, F. Lemoine

\& D. Ünal

2011-02 The Interactions between the Credit Default Swap and the Bond Markets in Financial Turmoil

V. Coudert \& M. Gex

2011-01 Comparative Advantage and Within-Industry Firms M. Crozet \& F. Trionfetti Performance 
Organisme public d'étude et de recherche en économie internationale, le CEPII est placé auprès du Centre d'Analyse Stratégique. Son programme de travail est fixé par un conseil composé de responsables de l'administration et de personnalités issues des entreprises, des organisations syndicales et de l’Université.

Les documents de travail du CEPII mettent à disposition du public professionnel des travaux effectués au CEPII, dans leur phase d'élaboration et de discussion avant publication définitive. Les documents de travail sont publiés sous la responsabilité de la direction du CEPII et n'engagent ni le conseil du Centre, ni le Centre d'Analyse Stratégique. Les opinions qui y sont exprimées sont celles des auteurs.

Les documents de travail du CEPII sont disponibles sur le site $:$ http//www.cepii.fr. 